\title{
Toxicological and Epigenetic Studies of Two Types of Ale Beer, Tyrosol and Iso-Alpha Humulone
}

\author{
Tania Merinas-Amo ${ }^{1, *(\mathbb{D}}$, Rocío Merinas-Amo ${ }^{1}$, Rafael Font ${ }^{2}$, Mercedes del Río Celestino ${ }^{2}$ (D) \\ and Ángeles Alonso-Moraga ${ }^{1}$ \\ 1 Department of Genetics, University of Córdoba, 14071 Córdoba, Spain; rocio.merinas@gmail.com (R.M.-A.); \\ ge1almoa@uco.es (Á.A.-M.) \\ 2 Agri-Food Laboratory, CAGPDS, Avda. Menéndez Pidal s/n, 14080 Córdoba, Spain; \\ rafaelm.font@juntadeandalucia.es (R.F.); mercedes.rio.celestino@juntadeandalucia.es (M.d.R.C.) \\ * Correspondence: tania.meram@gmail.com
}

check for

updates

Citation: Merinas-Amo, T.;

Merinas-Amo, R.; Font, R.; del Río

Celestino, M.; Alonso-Moraga, Á.

Toxicological and Epigenetic Studies of Two Types of Ale Beer, Tyrosol and Iso-Alpha Humulone. Processes 2021,

9, 485. https://doi.org/10.3390/ pr9030485

Academic Editor: Raquel Rodríguez Solana

Received: 17 February 2021

Accepted: 4 March 2021

Published: 8 March 2021

Publisher's Note: MDPI stays neutral with regard to jurisdictional claims in published maps and institutional affiliations.

Copyright: (c) 2021 by the authors. Licensee MDPI, Basel, Switzerland. This article is an open access article distributed under the terms and conditions of the Creative Commons Attribution (CC BY) license (https:// creativecommons.org/licenses/by/ $4.0 /)$.

\begin{abstract}
Although many benefits drawn from beer consumption are claimed, the epidemiological records are contradictory with respect to cancer prevention. The purpose of this study was to investigate the possible health-related activities involving genome safety and the ageing processes of two types of lyophilised ale beers (blond and stout), as well as two of their bioactive compounds (tyrosol and iso-alpha humulone). A multipurpose trial set of in vivo toxicity, antitoxicity, mutagenicity, antimutagenicity, lifespan and healthspan assays using Drosophila melanogaster were used. In parallel, several in vitro assays were designed using the cancer cell line HL-60 in order to establish the possible chemopreventive activity of the selected substances, where epigenetic modulation of DNA methylation changes, clastogenic activity and tumour cell inhibition growth were evaluated. The safety of the four substances was confirmed: lyophilised blond ale beer (LBAB), lyophilised stout ale beer (LSAB), tyrosol and iso-alpha humulone were neither toxic nor genotoxic. Moreover, all substances, except tyrosol, revealed the ability to protect individual genomes against oxidative radicals and to exert antimutagenic activity against the genotoxin hydrogen peroxide. With respect to the degenerative process indicators of lifespan and healthspan, tyrosol was the only compound that did not exert any influence on the life extension of Drosophila; LBAB induced a significant lifespan extension in D. melanogaster; LSAB and its distinctive compound iso-alpha humulone induced a reduction in longevity. The in vitro assays showed the cytotoxic activity of LBAB, LSAB and tyrosol against HL-60 cells. Moreover, proapoptotic DNA fragmentation or DNA strand breakage was observed for both types of beers and iso-alpha humulone at different concentrations. Furthermore, the lyophilised ale beers and tyrosol exhibited an increasing genome-wide methylation status, while iso-alpha humulone exhibited a demethylation status in repetitive cancer cell sequences. Although the biological activities assigned to beer consumption cannot be linked to any specific molecule/element due to the complexity of the phenolic profile, as well as the multifactor brewing process, the results obtained let us propose lyophilised ale beers as safe potential nutraceutical beverages when consumed in moderate amounts. The prevention of toxicity and genetic oxidative damage, as well as the induction of tumor cell death and modulation of the methylation status, are the key activities of beer that were shown in the present research.
\end{abstract}

Keywords: ale beer; iso-alpha humulone; tyrosol; Drosophila; genotoxicity; longevity; HL-60 cells; apoptosis; methylation

\section{Introduction}

Dietary constituents can influence the carcinogenesis process at various stages through a variety of mechanisms. Several nutrients, specific foods and food patterns are believed to be particularly chemopreventive, although little is known about the mechanisms underlying cancer prevention [1,2]. 
Nonetheless, it is well known that both genes and environmental external factors play essential roles in human development and gene expression [3]. Internal elements, such as genes, can be strongly influenced (turned on/off) by external factors, such as temperature, chemicals or light. All these factors acting together will affect the way an organism develops and functions [4].

Beer is the alcoholic beverage of choice in many countries and the most consumed one [5]. This complex beverage is nowadays basically made from malt, hops (Humulus lupulus), water and brewer's yeast. The most remarkable difference relative to other worldwide beverages (water and tea) is its high content in essential nutrients, such as minerals, vitamins, amino acids and the most interesting non-nutrient elements, such as phenolics [6]. The hops ${ }^{\prime}$ contribution to beer phenolics accounts for around $30 \%$ of the total [7]. The type and quality of beer depend on the brewing, where a series of factors influence this process, with the most crucial being the barley entry, as well as the malting process, $\mathrm{pH}$ and temperature during mashing, sparging and boiling, along with the variety of hops used and yeast fermentation.

A fermentation process in which "top-fermenting" yeast $\left(20\right.$ to $\left.25^{\circ} \mathrm{C}\right)$ is acting produces ale-type beer. Beer can either be consumed right after this step or undergo a short period of ageing [8].

Some beer compounds are highly recommended for improving health. Several activities related to degenerative/ageing/oxidative processes have been described for beer compounds besides the antimicrobial ones. Nevertheless, the limited epidemiological data are not enough, as there are no clinical assays supporting them, precisely in dermatology, where fair bioassays are difficult to develop. Consequently, adequate trials are needed to ensure the safe and correct use of such substances and to eventually be able to advise regular/moderate beer consumption [7].

It is known that moderate consumption of alcoholic drinks is related to a reduction in mortality rates in humans when compared to those that do not drink alcohol [9]. Epidemiological data provide a positive association between beer consumption and a lower risk of suffering cardiovascular disease. Approximately $50 \%$ of blood cholesterol comes from one's diet [10]. Furthermore, the use of beer could counteract kidney stone development [11].

Several molecules contained in beer belonging to the phenol and vitamin groups are often claimed to be health promoters because they are involved in the reduction/remission of age-related diseases [12]. Some of them are included in the crude materials used in the brewing process (alive yeast, barley and hops) and can be detected in the final product alongside the new molecules produced during brewing [13].

We focused this research on two phenolics that are present in beers: tyrosol, as the most abundant simple phenol present in all beer, and iso-alpha humulone, as a specific phenolic constituent of hops that is found at high levels in stout beers.

Tyrosol, 4-(2-hydroxyethyl)phenol, is a natural phenolic antioxidant that is abundant in wine, virgin olive oil, vermouth and beer, recently becoming very popular as a result of diet advice [14]. This aromatic alcohol is produced via fermentation of the amino acid tyrosine and is present at exceptionally high concentrations (up to $40 \mathrm{mg} / \mathrm{L}$ ) in beers [15]. Although the absolute antioxidant activity of tyrosol is lower than its hydroxyl form, hydroxytyrosol (2-(30,40-dihydroxyphenyl)ethanol) [16,17], several cellular experimental models reported potent biological activities for tyrosol, which seem not to be related to the lower in vitro activity reported [18-20]. The Caenorhabditis elegans animal model has been used to study the bioactivities of tyrosol by Cañuelo et al. [21], revealing that this phenol improves the survival stress-resistance curves. The epidemiological data about the high longevity rates for humans in the Mediterranean area could be caused by the higher intake of olive oil and wine, which are known to contain high concentrations of tyrosol [22].

Hops contain humulone, which is a distinctive molecule whose isomere, iso-alpha humulone, confers the bitter taste to beer [23]. This isomere is retained in mature beer, reaching concentrations of up to $100 \mathrm{mg} / \mathrm{L}$ in some bitter ales [24]. The most important class of hop compounds are the hop acids, which are distinguished as alpha acids (humulones) 
and beta acids (lupulones) [12]. Beta acids are extremely sensitive to oxidation and do not survive the brewing process, whereas the transformations of the humulones during wort boiling have been studied in great detail. The most important chemical conversion during the brewing of beer is the isomerisation of alpha acids to iso-alpha acids; this process is involved in the generation of the bitter flavour of beer [25]. Iso-alpha humolone is considered as one of the most essential components of beer derived from hops due to its physicochemical characteristics in solutions and surfaces [26]. Moreover, several studies support the important role that isohumulone plays in beer foam stability, which is considered a major and valuable property of beer [27]. Furthermore, this phenol has an important function in beer as it is able to protect beer from spoilage by hindering the growth of Lactobacillus in a dose-dependent manner [28].

Previous in vivo and in vitro studies with two types of hops in model organisms support the beneficial claims that this substance is safe, nutraceutical and chemopreventive [29]. In addition to its anti-inflammatory and antioxidative effects, the hop bitter acids also exhibit Gram-positive antibacterial activity [30]. Humulone can suppress the TNF- $\alpha$-dependent cyclooxygenase- 2 induction with an $\mathrm{IC}_{50}$ as low as about $30 \mathrm{nM} / \mathrm{L}$ in comparison to dexamethasone, which does it at $1 \mathrm{nM} / \mathrm{L}$ [31]. Topical application of humulone exhibited an anticarcinogenic effect via suppressing TPA-induced activation of NF- $\mathrm{kB}$ in mouse skin stimulated with the tumour promoter 12-O-tetradecanoylphorbol-13-acetate (TPA) [32]. The potent angiogenic inhibitor activity of humulone is remarkable [33]. Many beer compounds are able to regulate sleeping rhythm, basically due to their hop content and precisely due to their alpha acid components [34]. Taking into account the above information about hops, many clues point towards humulone as the key molecule for the various biological activities that are assigned to hops.

Many foods are claimed to have medicinal/nutraceutical purposes that provide preventive/curative effects for several illnesses. A nutraceutical substance should not only be non-toxic but should also be able to prevent toxicity, avoid genetic oxidative damage, modulate the epigenome marks and induce cell apoptosis in tumour cells [35].

The frame of the present research is to explore the possibility to propose new substances with therapeutic potential and consider them as an essential element for the daily diet. The specific objective of our study was to evaluate the biological effects of two types of lyophilised ale beers (a blond and a stout one) and two of their most important bioactive components, namely, tyrosol and iso-alpha humulone, on degenerative processes. Towards this goal, a multipurpose trial investigating the biological activity at the individual, cellular and molecular levels drawn from the in vivo and in vitro assays was carried out using two model systems. The Drosophila animal model, which contains more than 70\% of human disease homologous genes [36], is a choice system to assay toxicity, mutagenicity, longevity and many degenerative processes [37]. Additionally, the human leukaemia cells (HL-60) in vitro model system was used in parallel to study the cytotoxicity, DNA damage and the modulation of methylation status caused by the selected substances.

\section{Materials and Methods}

\subsection{Sample Preparation and Simple Compounds}

A blond ale beer (Judas ${ }^{\circledR}$, originally from Alken-Maes de Waarloos, Belgium) and a stout ale beer (Guinness ${ }^{\circledR}$, originally from St. James's Gate Brewery, Ireland) both obtained in a local Spanish market, were selected for this study. Furthermore, the molecules 4-(2hydroxyethyl)phenol (tyrosol) (TCI) and iso-alpha humulone (Aroxa ${ }^{\mathrm{TM}}$, Cara Technology LTD Randalls Road Leatherhead, Surrey KT22 7RY, UK) contained in beer were selected to be studied as single bioactive compounds. The different concentrations of single molecules were determined in order to obtain their equivalent amount to the different concentrations found in the beers.

Before carrying out the bioassays, the beers were lyophilised (SCAI, Servicio Central de Apoyo a la Investigación, University of Córdoba, Córdoba, Spain) with the aim to obtain a wide range of concentrations to be checked. 
Taking into account the daily food intake of Drosophila [38], the concentrations of each compound were calculated to make them equivalent to the average for the same period in humans (192 mL/day) [39].

\subsection{In Vivo Assays}

Drosophila melanogaster

Drosophila is used as a model organism in bioassays as it is useful for uncovering insights that are important for humans, including degenerative processes, such as cancer and ageing [40-42]. Two types of Drosophila strains were used, with each one characterised by mutations in chromosome III:

- $\quad m w h / m w h$, a recessive mutation (multiple wing hairs) that induces multiple hairs per homozygous cell instead of one per cell in the wild-type phenotype [43].

- $\quad \mathrm{flr}^{3} / \mathrm{In}$ (3LR) TM3, rip $\mathrm{p}^{\mathrm{sep}} b x^{34 e} e^{\mathrm{s}} B d^{S}$, where the $f l r^{3}$ (flare) mutation is homozygous recessive lethal and cells carrying both doses are able to produce deformed hairs in the late stages of larval development [44].

Strains were grown at $25{ }^{\circ} \mathrm{C}$ and $80 \%$ relative humidity $(\mathrm{RH})$ conditions in a medium containing yeast, $\mathrm{NaCl}$, agar-agar, sucrose, propionic acid, streptomycin and water. Reciprocal crosses for the different assays were established using virgin female flies obtained from the two strains.

\subsubsection{Toxicity and Antitoxicity Assays}

In the toxicity assays, we evaluated the percentage of treated individuals that survived relative to the concurrent control. The concentrations assayed ranged from $3.125-50 \mathrm{mg} / \mathrm{mL}$ for lyophilised blond ale beer (LBAB) and lyophilised stout ale beer (LSAB), 0.127-2.026 mM for tyrosol and 1.207-77.25 mM for iso-alpha humulone. To perform the antitoxicity assays, the tested concentrations were combined by adding the mutagen and toxic hydrogen peroxide at 0.12 M (Sigma, H1009, Sigma Chemical CO., St. Louis, MO 63178 USA) [45]. Negative concurrent controls were prepared with medium and distilled water; meanwhile, positive controls were made with medium, distilled water and combined with $0.12 \mathrm{M}$ $\mathrm{H}_{2} \mathrm{O}_{2}$ [35]. To evaluate the results, we used the nonparametric chi-squared test.

\subsubsection{Genotoxicity and Antigenotoxicity Assays (SMART)}

The methodology described by Graf et al. [46] was followed in both assays. The tubes contained $0.85 \mathrm{~g}$ of Drosophila Instant Medium (Formula 4-24, Carolina Biological Supply, Burlington, NC, USA) and $4 \mathrm{~mL}$ of the different concentrations of each tested substance $(3.125$ and $50 \mathrm{mg} / \mathrm{mL}$ of LBAB and LSAB; 0.127 and 2.026 of tyrosol; 2.414 and 77.25 of iso-alpha humulone). To evaluate the antigenotoxicity potential, combined treatments of genotoxin $\left(0.12 \mathrm{M} \mathrm{H}_{2} \mathrm{O}_{2}\right)$ and the same concentration of LBAB, LSAB, tyrosol or iso-alpha humulone as that used in the genotoxicity assays were established. The wings of transheterozygous emerged individuals $\left(m w h f l r^{+} / m w h^{+} f l r^{3}\right)$ were scored at $400 \times$ magnification. According to the wing hair spots, mutations could be grouped into three different categories: small single spots (mutation induced in one or two cells), large single spots (with three or more cells showing $m w h$ or $f l r^{3}$ phenotypes), or twin spots (showing both $m w h$ and $\mathrm{flr}^{3}$ phenotypes together). Somatic point mutations, chromosome aberrations and somatic recombinations produced small and large single spots; meanwhile, twin spots were exclusively produced by the somatic recombination of the centromere and the $\mathrm{flr}^{3}$.

A total of 361 and 358 wings were mounted and analysed for the genotoxicity and antigenotoxicity treatments, respectively. Negative/positive/inconclusive results were obtained by comparing the control and treatment mutational frequencies and applying the Kastenbaum and Bowman binomial test $[47,48]$. The nonparametric Mann-Whitney $U$ test ( $\alpha=\beta=0.05$ ) was used to analyse the inclusive and positive results. Finally, the 
inhibition percentages (IPs) for the combined treatments were calculated from the total spots per wing using the following formula [49]:

$$
\mathrm{IP}=[(\text { single genotoxin }- \text { combined treatment }) / \text { single genotoxin }] \times 100 .
$$

\subsubsection{Lifespan Assays}

Trials were performed at $25{ }^{\circ} \mathrm{C}$ following the Tasset-Cuevas et al. [45] methodology. Cohorts of 25 female and male flies were placed into specials tubes containing different concentrations of the compounds studied (3.125-50 mg/mL of LBAB and LSAB; $0.127-2.026 \mathrm{mM}$ of tyrosol; $2.414-77.25 \mathrm{mM}$ iso-alpha humulone). A total of four sets were monitored during the complete life extension, renewing the media twice a week.

As a way to know the healthspan of the treated Drosophila, we analysed the upper $25 \%$ of the lifespan survival curves, as the quality of life is characterised by low and more-or-less constant age-specific mortality rate values [50].

The SPSS Statistics 17.0 software (SPSS software, Inc., Chicago, IL, USA) was used to calculate the survival curves using the Kaplan-Meier method and the significance was assessed using the log-rank test.

\subsection{In Vitro Cytotoxicity Assays \\ 2.3.1. Cell Culture}

The human promyelocytic leukaemia cell line HL-60 was maintained in supplemented RPMI-1640 medium (Sigma, R5886) and grown at $37^{\circ} \mathrm{C}$ in a humidified atmosphere of $5 \%$ $\mathrm{CO}_{2}$ [51]. Moreover, cultures were routinely plated at $2.5 \times 10^{4}$ cells $/ \mathrm{mL}$ concentration in $10 \mathrm{~mL}$ culture bottles and replated three times a week to keep them in optimal conditions.

\subsubsection{Cytotoxicity Assay}

To carry out this assay, HL-60 cells were placed in 96-well culture plates $\left(2 \times 10^{4}\right.$ cells $\left./ \mathrm{mL}\right)$ and treated for $72 \mathrm{~h}$ with LBAB, LSAB, tyrosol and iso-alpha humulone at different concentrations (3.125-250 mg/mL for the beers; $0.127-2.026 \mathrm{mM}$ for tyrosol; $1.207-38.62 \mathrm{mM}$ for iso-alpha humulone). The above concentration intervals were selected to evaluate the cytotoxic dose ranges the in vivo lethality value or a $50 \%$ inhibitory concentration $\left(\mathrm{IC}_{50}\right)$ when possible. Cell viability was determined by the trypan blue dye exclusion assay using a Neubauer chamber (Neubauer Double, Zuzi, Depth $0.100 \mathrm{~mm}, 0.0025 \mathrm{~mm}^{2}$ ) at $100 \times$ magnification (AE30/31, Motic microscope, Cabrera de Mar, Barcelona, Spain). Survival curves were plotted in a graph as a viability percentage of at least three independent assays relative to the non-treated control growing for $72 \mathrm{~h}$.

\subsubsection{Determination of DNA Fragmentation}

HL-60 cells $\left(1 \times 10^{6}\right.$ cells $\left./ \mathrm{mL}\right)$ were incubated with different concentrations of lyophilised beers, tyrosol or iso-alpha humulone $(3.125-250 \mathrm{mg} / \mathrm{mL} ; 0.127-2.026 \mathrm{mM}$; 0.603-154.5 mM, respectively) for $5 \mathrm{~h}$. Then, the cells were collected via a centrifugation process at $603.72 \times g$ for $5 \mathrm{~min}$ and DNA was isolated according to the methodology described by Merinas-Amo et al. [52]. Summarily, lysis step, with SDS and proteinase K; precipitation step, with $\mathrm{NaCl}$ and isopropanol; washing step, with ethanol; incubation step with RNAse treatment; quantification and finally visualisation of $1200 \mathrm{ng} / \mathrm{sample}$ in agarose/ethidium bromide gel.

\subsubsection{Comet Assay}

The alkaline comet assay $(\mathrm{pH}<13)$, following the method previously described [53-55] with some modifications, was used to determine the induction of DNA strand breaks. Cells were treated with LBAB and LSAB $(7.56,31.25$ and $62.5 \mathrm{mg} / \mathrm{mL})$, tyrosol $(0.127,0.253$ and $0.506 \mathrm{mM})$ and iso-alpha humulone $(1.207,4.828$ and $19.31 \mathrm{mM})$ for $5 \mathrm{~h}$. After carrying out the washing steps in PBS, a concentration of $6.25 \times 10^{5}$ cells $/ \mathrm{mL}$ were combined with 0.75\% low-melting-point agarose (Sigma, A4018) and removed onto frost-ended slides. 
The cells underwent several lysis, alkaline electrophoresis, neutralisation and drying steps according to Mateo-Fernández et al.'s [56] protocol. Finally, the DNA of 50-100 single cells was visualised by treating the slides with $7 \mu \mathrm{L}$ of a $10 \mu \mathrm{g} / \mathrm{mL}$ stock solution of propidium iodide (Sigma, P4170). To analyse the comet images, we used a Leica DM 2500 fluorescence microscope (at $400 \times$ magnification) with a green filter and an attached camera (JAI CV$\mathrm{M} 4 \mathrm{CL}$, Barcelona, Spain) and the DNA parameters were analysed with the OpenComet plugin from ImageJ (NIH).

Statistical analysis was undertaken using the SPSS Statistics 17.0 software. The main parameters of the comet imaging were the total DNA, percentage of DNA in the comet and tail, tail length and tail moment (TM). The last parameter was the single-most relevant index of DNA damage, which is calculated as the percent DNA in the tail multiplied by the distance between the means of the head and tail distributions $[53,54]$. Moreover, the TM is considered appropriate for regulatory or interlaboratory comparison studies [57]. The significant effect of each compound on HL-60 cell DNA integrity was analysed by studying the TM values obtained in a one-way ANOVA.

\subsubsection{Methylation Status}

To analyse the methylation status of the nucleotides, the DNA was obtained using the same protocol for the DNA fragmentation section. Then, a bisulphite-modified DNA step (EZ DNA Methylation-Gold Kit) involving the LBAB (15.625 and $250 \mathrm{mg} / \mathrm{mL}$ ), LSAB (15.625 and $250 \mathrm{mg} / \mathrm{mL}$ ), tyrosol ( 0.127 and $2.025 \mathrm{mM}$ ) and iso-alpha humulone ( 9.65 and $38.725 \mathrm{mM}$ ) treatments was used as a template for fluorescence-based real-time quantitative methylation-specific PCR (qMSP). Finally, a qMSP was performed in a MiniOpticon RealTime PCR System (MJ Mini Personal Thermal Cycler, Bio-Rad Laboratories Inc., Hercules, CA, USA), following the protocol described by Merinas-Amo et al. [52], and the results were analysed using Bio-Rad CFX Manager 3.1 software.

We selected repetitive elements to cover an extensive range of human genomic DNA since Alu and LINE (Long Interspersed Nuclear Element) sequences are interspersed throughout the genome and satellite DNA is confined to the centromere areas [58-61]. The obtained relative results were normalised with the housekeeping sequence Alu C4 using the Nikolaidis et al. [62] and Liloglou et al. [63] comparative Ct method. Assays were analysed three times per sample. To evaluate the differences between the methylation levels in the treated HL-60 cells at the selected repetitive elements, both one-way ANOVA and post hoc Tukey's tests were used. The selected repetitive sequences (Alu M1, LINE-1 and Sat- $\alpha$ ) were acquired from Isogen Life Science (see Table 1 for detailed information [64]).

Table 1. Primers information.

\begin{tabular}{|c|c|c|c|c|c|c|c|}
\hline $\begin{array}{l}\text { Reaction. } \\
\text { ID }\end{array}$ & $\begin{array}{l}\text { GenBank } \\
\text { Number }\end{array}$ & \multicolumn{2}{|c|}{ Amplicon } & $\begin{array}{c}\text { Forward Primer } \\
\text { Sequence } \\
5^{\prime} \text { to } 3^{\prime}(N)\end{array}$ & $\begin{array}{c}\text { Reverse Primer } \\
\text { Sequence } \\
5^{\prime} \text { to } 3^{\prime}(N)\end{array}$ & \multicolumn{2}{|c|}{$\begin{array}{l}\text { GC Content (\%) } \\
\text { Forward Reverse }\end{array}$} \\
\hline Alu C4 & $\begin{array}{l}\text { Consensus } \\
\text { Sequence }\end{array}$ & 1 & 98 & $\begin{array}{c}\text { TAGTGGTTT } \\
\text { AT ATTTGTA } \\
\text { ATTTTAGTA }(36)\end{array}$ & $\begin{array}{l}\text { ACT АATCTT } \\
\text { AАACTCCTA } \\
\text { ACCTCA (33) }\end{array}$ & 25 & 27.3 \\
\hline Alu M1 & Y07755 & 5059 & 5164 & $\begin{array}{c}\text { ATTATGTTA } \\
\text { GTTAGGATG } \\
\text { GTTTCGATT } \\
\text { TT (29) }\end{array}$ & $\begin{array}{c}\text { CAATCGACC } \\
\text { GAACGCGA } \\
(17)\end{array}$ & 27.6 & 58.8 \\
\hline LINE-1 & X52235 & 251 & 331 & $\begin{array}{l}\text { GGACGT ATT } \\
\text { TGGAAAATC } \\
\text { GGG (21) }\end{array}$ & $\begin{array}{c}\text { AATCTCGCG } \\
\text { AT ACGCCGT } \\
\text { T (19) }\end{array}$ & 47.6 & 52.6 \\
\hline Sat- $\alpha$ & M38468 & 139 & 260 & $\begin{array}{l}\text { TGATGGAGT } \\
\text { ATTTTTAAA } \\
\text { AT ATACGTT } \\
\text { TTGTAGT (34) }\end{array}$ & $\begin{array}{l}\text { AATTCTAAA } \\
\text { AAT ATTCCT } \\
\text { CTTCAATTA } \\
\text { CGTAAA (33) }\end{array}$ & 23.5 & 21.2 \\
\hline
\end{tabular}




\section{Results and Discussion}

\subsection{In Vivo}

\subsubsection{Toxicity and Antitoxicity}

The relative percentage of adults after the larvae treatment with LBAB, LSAB, tyrosol and iso-alpha humulone is shown in Figure 1A. The survival rates were statistically insignificant and equal to the concurrent water controls, with the only exception being the highest tested concentration of tyrosol $(2.026 \mathrm{mM})$, which exhibited a toxic effect on the Drosophila viability, with an $83 \%$ survival rate. The antitoxicity assays revealed the ability of the LBAB, LSAB, tyrosol and iso-alpha humulone to protect adult individuals against oxidative stress.

(A)

LSAB

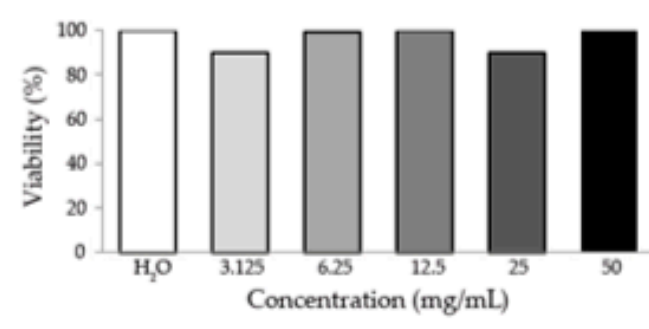

LBAB

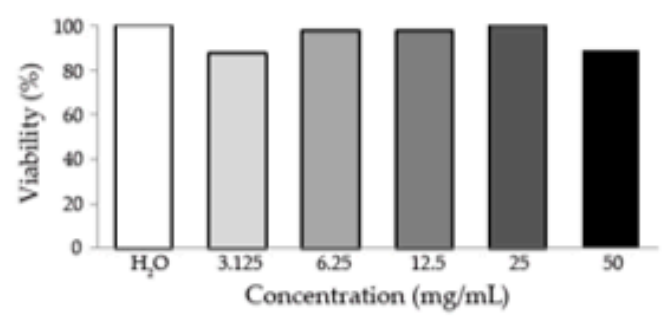

TYROSOL

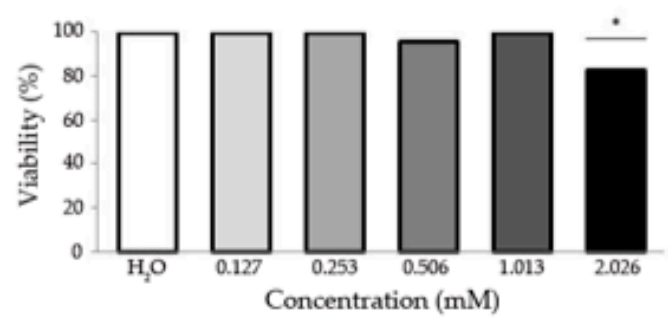

ISO-ALPHA HUMULONE

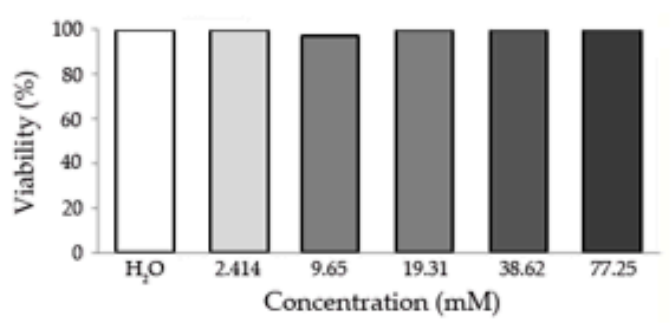

(B)

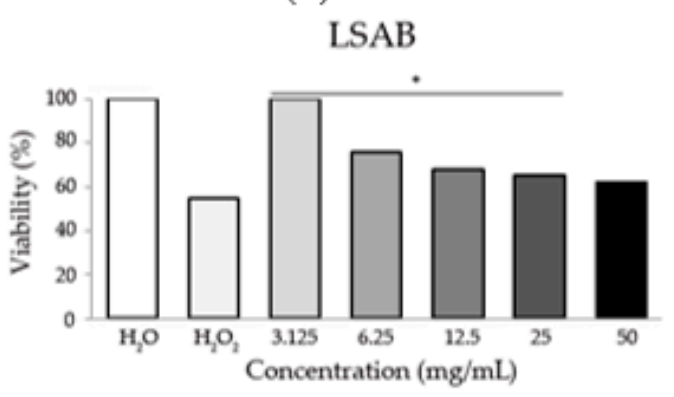

LBAB

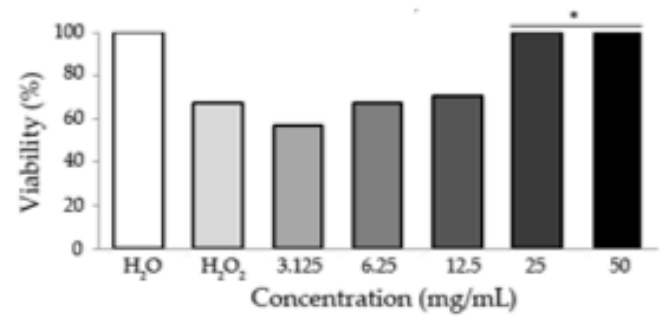

TYROSOL

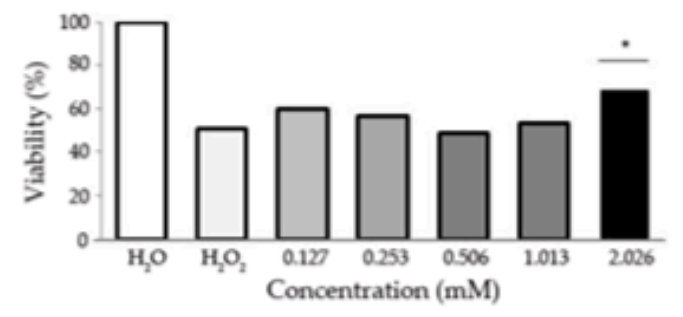

ISO-ALPHA HUMULONE

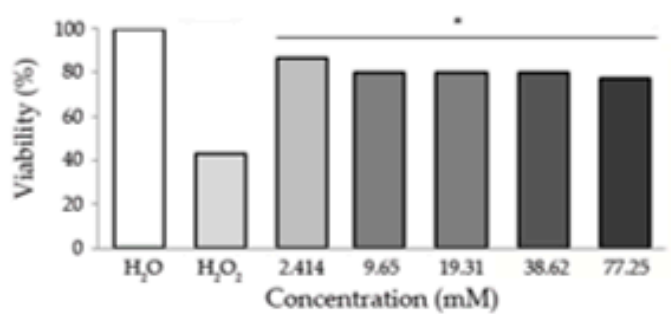

Figure 1. (A) Toxicity and (B) antitoxicity levels of lyophilised blond ale beer (LBAB), lyophilised stout ale beer (LSAB), tyrosol and iso-alpha humulone in D. melanogaster. Data are shown as the percentage of surviving adults relative to 300 untreated 72-h-old larvae from three independent assays fed with different concentrations of LBAB, LSAB, tyrosol and iso-alpha humulone (A) and combined treatment with $0.12 \mathrm{M} \mathrm{H}_{2} \mathrm{O}_{2}$ (B). * : significant differences relative to the positive control. The chi-squared value was higher than 3.84 . 
The positive control consisted of $\mathrm{H}_{2} \mathrm{O}_{2} \quad 0.12 \mathrm{M}$ treatments and a reduced survival rate of up to $54 \%$ relative to the $\mathrm{H}_{2} \mathrm{O}$ control; this value fell into the previous ranges published for toxicity in Drosophila melanogaster treated with this same toxicant [65]. Gorjanovic et al. [66] used $\mathrm{H}_{2} \mathrm{O}_{2}$ to evaluate the antioxidative capacity of beer. In agreement with these previous results, here we found that $\mathrm{LBAB}$ showed a significant protective effect at the two highest assayed concentrations ( 25 and $50 \mathrm{mg} / \mathrm{mL}$ ) and LSAB at all concentrations, except at the highest one $(50 \mathrm{mg} / \mathrm{mL})$. The combined treatments of tyrosol and $\mathrm{H}_{2} \mathrm{O}_{2}$ showed a significant protective effect only in the highest concentration assayed $(2.026 \mathrm{mM})$. Finally, iso-alpha humulone was the most protective substance, with significant protective effects shown for all the assayed concentrations.

Unfortunately, not much information about the toxicity and antitoxicity of ale beer was found. Up to date, there are no previous studies about the effects that ale beers cause on the survival and protection of D. melanogaster. By comparing our results with other studies on lager beer [52], the nontoxic activity of both types of beers was confirmed, although lager beer shows a higher protective effect against $\mathrm{H}_{2} \mathrm{O}_{2}$ than ale beers. Tyrosol has been linked to antimicrobial/toxic activity against several bacterial strains [67]. Furthermore, the hop acids exhibit bacteriostatic activity due to their potential for inhibiting the growth of Gram-positive bacteria. This remarkable bioactivity is of great importance for eliminating microorganisms during wort boiling, which eventually results in a naturally sterile beer [68]. These antimicrobial activities of phenols are not related to the safe properties that beers showed in our toxicity test in the Drosophila higher organism. Nevertheless, these antimicrobial activities can be considered as an added value to beer properties. A study with two types of hops (saazer and sladek) showed nontoxic effects in the Drosophila model organism as the $50 \%$ lethal dose $\left(\mathrm{LD}_{50}\right)$ was never reached at the assayed concentrations [29]. The present results of iso-alpha humulone showed, in part, that it is the molecule responsible for the hops lack of toxicity. This differential behaviour of tyrosol as a procaryotic with respect to toxicity confirmed the high potential of using Drosophila as a higher model organism.

Oxidative stress and reactive oxygen species are associated with diverse diseases [69]. The chemical structure of flavonoids (number and position of double bonds, ortho-3,4dihydroxy moiety, hydroxyl groups) are important for their free radical scavenging and antioxidant activities [70]. It has also been reported that tyrosol is a moderate but stable antioxidant [71]. Nevertheless, studies in kidney cells showed that tyrosol (25-2500 $\mu \mathrm{M})$ does not exert any protective effect [72], which is a result that agrees with ours in HL-60 cells. Another antioxidant contained in beer comes from the roasting of malt, where coloured products (resulting from the Maillard reaction) are produced and whose peroxyl radical scavenging potential is well known [73]. This fact could be responsible for the stronger antitoxic potential of LSAB at lower concentrations compared to the LBAB. Therefore, taking into account their polyphenol content, beer could be considered a good free radical scavenger. Moreover, our results are in agreement with the already demonstrated antioxidant ability of blond and stout ale beers $[74,75]$. For these reasons, it can be said that beer is not toxic and safe in the Drosophila melanogaster animal model. In fact, it is antitoxic and protects against the oxidative toxin $\mathrm{H}_{2} \mathrm{O}_{2}$ due to its polyphenol content. A previous study by Merinas-Amo et al. [29] with two types of hops support the antioxidant power that this beer's raw materials have on Drosophila when they are combined with a toxic agent.

\subsubsection{Genotoxicity and Antigenotoxicity}

Table 2 exhibits the results of the genotoxicity and antigenotoxicity assays in the SMART test. The negative control showed a frequency of mutations per wing (0.157) that fell into the historical range for the wing spot test [76]. 
Table 2. Genotoxicity and antigenotoxicity of lyophilised blond ale beer (LBAB), lyophilised stout ale beer (LSAB), iso-alpha humulone and tyrosol in the Drosophila wing spot test.

\begin{tabular}{|c|c|c|c|c|c|c|c|c|c|}
\hline \multicolumn{10}{|c|}{ Clones per Wing (No. of Spots) ${ }^{(1)}$} \\
\hline \multirow{2}{*}{$\begin{array}{c}\text { Compound } \\
\mathrm{H}_{2} \mathrm{O}\end{array}$} & \multirow{2}{*}{$\begin{array}{c}\text { Number } \\
\text { of Wings }\end{array}$} & \multicolumn{2}{|c|}{$\begin{array}{c}\text { Small Single } \\
\text { Clones } \\
\text { (1-2 Cells) } \\
\text { m = } 2\end{array}$} & \multirow{2}{*}{$\begin{array}{c}\text { Large } \\
\text { Simple } \\
\text { Clones } \\
\text { (>2 Cells) } \\
\mathrm{m}=5 \\
0\end{array}$} & \multirow{2}{*}{$\begin{array}{c}\begin{array}{c}\text { Twin } \\
\text { Clones } \\
\mathbf{m}=5\end{array} \\
0\end{array}$} & \multicolumn{2}{|c|}{$\begin{array}{c}\text { Total Clones } \\
\quad \mathbf{m}=2\end{array}$} & \multirow[t]{2}{*}{$\begin{array}{c}\text { Mann } \\
\text {-Whitney } \\
U \text { test }^{(2)}\end{array}$} & $\begin{array}{c}\text { Inhibition } \\
\text { Percentage } \\
(\%)^{(3)}\end{array}$ \\
\hline & & 0.157 & (6) & & & 0.157 & $(6)$ & & \\
\hline $\mathrm{H}_{2} \mathrm{O}_{2}$ & 36 & 0.305 & (11) & $0.083(3)$ & 0 & 0.388 & $(14)+$ & & \\
\hline \multicolumn{10}{|c|}{ SIMPLE TREATMENT } \\
\hline \multicolumn{10}{|c|}{ LBAB $(\mathrm{mg} / \mathrm{mL})$} \\
\hline 3.125 & 39 & 0.154 & $(6)$ & 0 & 0 & 0.154 & (6) $\mathrm{i}$ & $\Delta$ & \\
\hline 50 & 38 & 0.263 & (10) & $0.026(1)$ & 0 & 0.289 & (11) i & $\Delta$ & \\
\hline \multicolumn{10}{|c|}{ LSAB (mg/mL) } \\
\hline 3.125 & 42 & 0.190 & (8) & $0.047(2)$ & 0 & 0.238 & $(10) \mathrm{i}$ & $\Delta$ & \\
\hline 50 & 44 & 0.159 & (7) & $0.091(4)$ & $0.022(1)$ & 0.273 & (12) $\mathrm{i}$ & $\Delta$ & \\
\hline \multicolumn{10}{|c|}{ Tyrosol (mM) } \\
\hline 0.127 & 40 & 0.263 & $(10)$ & $0.105(4)$ & $0.026(1)$ & 0.395 & $(15) \mathrm{i}$ & $\Delta$ & \\
\hline 2.026 & 40 & 0.175 & $(7)$ & 0 & 0 & 0.175 & (7) $\mathrm{i}$ & $\Delta$ & \\
\hline \multicolumn{10}{|c|}{$\begin{array}{l}\text { Iso-alpha humulone } \\
\qquad(\mathrm{mM})\end{array}$} \\
\hline 2.414 & 40 & 0.150 & (6) & 0 & 0 & 0.150 & (6) $\mathrm{i}$ & $\Delta$ & \\
\hline 77.25 & 40 & 0.125 & (5) & $0.125(5)$ & 0 & 0.250 & (10) $\mathrm{i}$ & $\Delta$ & \\
\hline \multicolumn{10}{|c|}{ COMBINED TREATMENT WITH $\mathrm{H}_{2} \mathrm{O}_{2}(0.12 \mathrm{M})$} \\
\hline \multicolumn{10}{|c|}{ LBAB (mg/mL) } \\
\hline 3.125 & 40 & 0.275 & (11) & 0 & $0.025(1)$ & 0.300 & (12) $\gamma$ & & 22.68 \\
\hline 50 & 42 & 0.095 & (4) & $0.071(3)$ & 0 & 0.166 & (7) $\gamma$ & & 57.21 \\
\hline \multicolumn{10}{|c|}{ LSAB (mg/mL) } \\
\hline 3.125 & 40 & 0.175 & (7) & $0.025(1)$ & 0 & 0.200 & (8) $\gamma$ & & 48.45 \\
\hline 50 & 44 & 0.159 & (7) & 0 & 0 & 0.159 & (7) $\gamma$ & & 59.02 \\
\hline \multicolumn{10}{|c|}{ Tyrosol (mM) } \\
\hline 0.127 & 40 & 0.325 & (13) & $0.075(3)$ & 0 & 0.400 & (16) $\lambda$ & $\Delta$ & -3.09 \\
\hline 2.026 & 40 & 0.325 & (13) & $0.100(4)$ & 0 & 0.425 & (17) $\lambda$ & $\Delta$ & -9.53 \\
\hline \multicolumn{10}{|c|}{$\begin{array}{l}\text { Iso-alpha humulone } \\
\qquad(\mathrm{mM})\end{array}$} \\
\hline 2.414 & 38 & 0.342 & (13) & 0 & 0 & 0.342 & (13) $\gamma$ & & 11.85 \\
\hline 77.25 & 38 & 0.289 & (11) & 0 & 0 & 0.289 & (11) $\gamma$ & & 25.51 \\
\hline
\end{tabular}

(1) Statistical diagnosis as stated by Frei and Wurgler [47]. + (positive) and i (inconclusive) against negative control; $\gamma$ (significantly different) and $\lambda$ (inconclusive) in contrast with the positive control. m: multiplication factor. Kastenbaum-Bowman test without a Bonferroni correction with probability levels of $\alpha=\beta=0.05$. (2) Inconclusive results were resolved using the Mann-Whitney $U$ test. The delta marker $(\Delta)$ means no differences between the treatment and the concurrent control. ${ }^{(3)}$ The inhibition percentages for the combined treatments were calculated using the total spots per wing based on Abraham [49].

The concentration of $\mathrm{H}_{2} \mathrm{O}_{2}$ used $(0.12 \mathrm{M})$ was demonstrated to be an inductor of somatic mutations and mitotic recombinations in Drosophila [65]. Our trials showed a total mutation rate of 0.388 spots/wing, which was double the water control.

LBAB, LSAB, tyrosol and iso-alpha humulone did not induce mutagenic activity at the tested concentrations. The total mutation rates at the lowest and highest concentrations of LBAB, LSAB, tyrosol and iso-alpha humulone ( 0.238 and 0.273 spots/wing, 0.154 and 0.289 spots/wing, 0.395 and 0.175 spots/wing, 0.150 and 0.250 spots/wing, respectively) were not significantly higher than the negative/water control ( 0.157 spots / wing). Moreover, LBAB, LSAB and iso-alpha humulone inhibited the genotoxic activity of $\mathrm{H}_{2} \mathrm{O}_{2}$ to mediumhigh extents of $48.45-59.02 \%, 22.68-57.21 \%$ and $11.85-25.51 \%$, respectively, at the lowest and highest tested concentrations. On the other hand, tyrosol did not exhibit significant antigenotoxic effects.

The polyphenol activity has been related to biological activities, such as antigenotoxicity [35]. Arimoto-Kobayashi et al. [77] indicated the antigenotoxic potential of beer components against heterocyclic amines (HCAs) using in vivo systems. Studies with ty- 
rosol in the SMART test showed that it was nongenotoxic and exhibited antigenotoxic activity against $\mathrm{H}_{2} \mathrm{O}_{2}$-induced damage at $140 \mu \mathrm{M}$ [35]. This finding was only comparable to our lower concentration. There are no data available on the in vivo antigenotoxic activity of iso-alpha humulone. Although similar previous studies carried out with two types of hops in Drosophila showed both no genotoxic or antigenotoxic activities against the $\mathrm{H}_{2} \mathrm{O}_{2}$ effects in the SMART test [29], our work showed the in vivo ability to protect DNA from oxidative damage of toxins for the first time. As we mentioned above, the antigenotoxic activity of hops could be due to the scavenging activity shown by this single molecule.

\subsubsection{Lifespan}

Longevity is a parameter that can be influenced by a wide variety of factors, including lifestyle, gender, diet, environmental influences, genetic variation, cultural influences and access to health care. Drosophila is an excellent system to study the longevity-promoting properties of nutraceutical extracts and compounds as adults have many of the cell senescence features of mammals [78-80].

Figure 2 shows the lifespan curves for LBAL, LSAB, tyrosol and iso-alpha humulone at different concentrations. LBAL produced a significant increase in Drosophila lifespan at the three lowest concentrations $(3.125,6.25$ and $12.5 \mathrm{mg} / \mathrm{mL})$, with an average longevity increase of 6 days compared to their concurrent control. Tyrosol did not significantly affect the longevity of Drosophila (longevity ranging between 56.2-63.046 days for the different concentrations) relative to the control (60.333 days on average) (Table 3$)$.
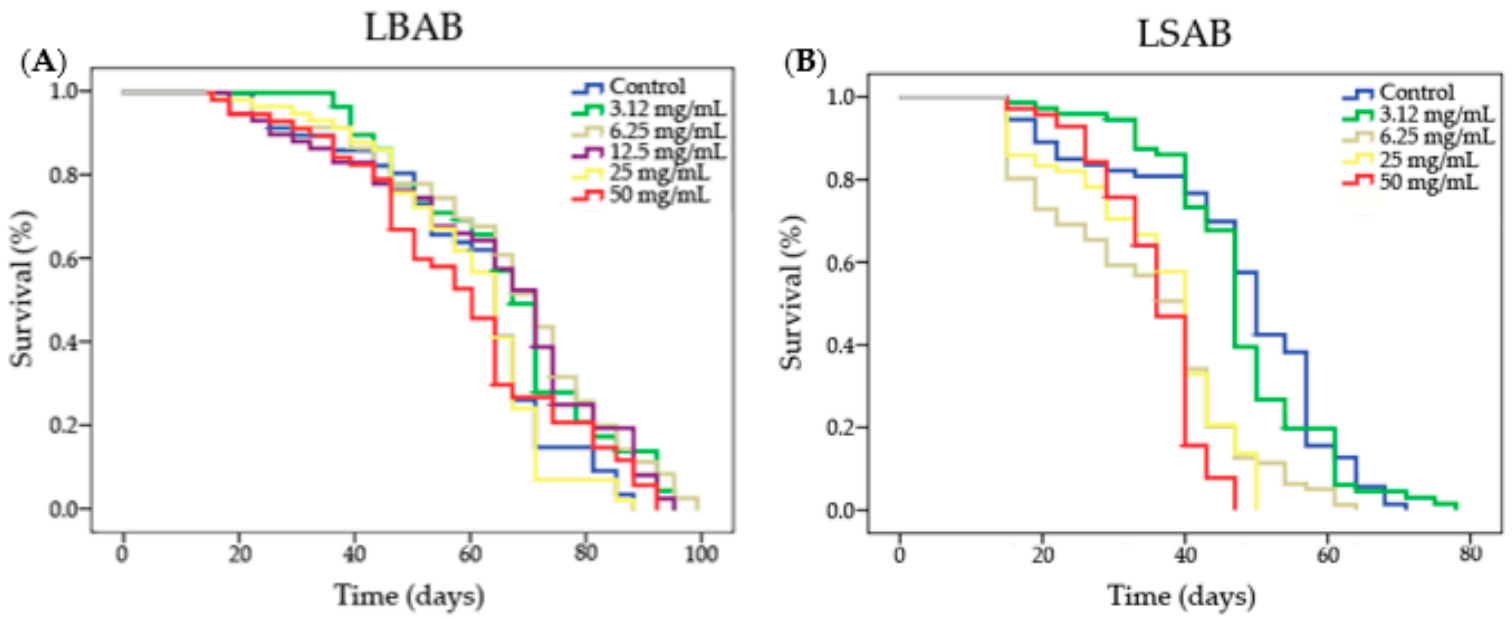

(C)

TYROSOL

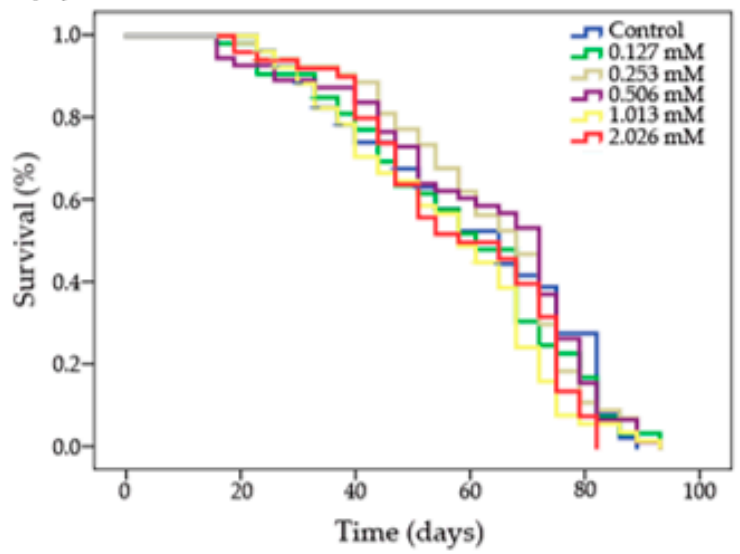

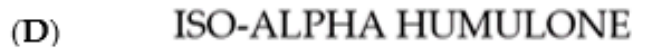

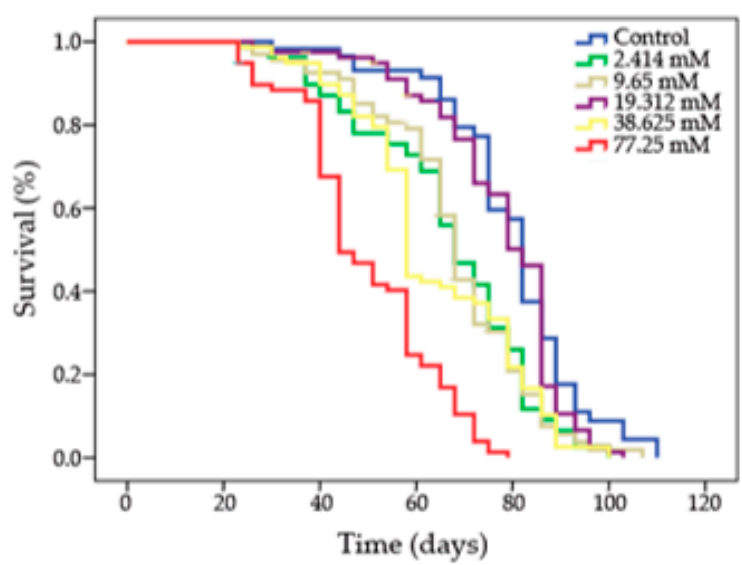

Figure 2. Survival curves of Drosophila melanogaster fed with different concentrations of lyophilised blond ale beer (LBAL) (A), lyophilised stout ale beer (LSAB) (B), tyrosol (C) and iso-alpha humulone (D) relative to the concurrent control. 
Table 3. Means and significances of the lifespan and healthspan curves.

\begin{tabular}{|c|c|c|c|c|c|}
\hline \multirow{2}{*}{ Compound } & \multirow{2}{*}{$\begin{array}{c}\text { Concentration } \\
\text { Control }\end{array}$} & \multicolumn{2}{|c|}{$\begin{array}{c}\text { Mean Lifespan (1) } \\
\text { (Days) }\end{array}$} & \multicolumn{2}{|c|}{$\begin{array}{c}\text { Mean Healthspan (1) } \\
\text { (Days) }\end{array}$} \\
\hline & & 60.104 & & 33.229 & \\
\hline \multirow{5}{*}{ LBAB } & $3.125 \mathrm{mg} / \mathrm{mL}$ & 66.176 & * & 42.500 & $* *$ \\
\hline & $6.25 \mathrm{mg} / \mathrm{mL}$ & 66.149 & * & 36.378 & ns \\
\hline & $12.5 \mathrm{mg} / \mathrm{mL}$ & 66.688 & $*$ & 31.750 & ns \\
\hline & $25 \mathrm{mg} / \mathrm{mL}$ & 59.474 & ns & 34.634 & $\mathrm{~ns}$ \\
\hline & $50 \mathrm{mg} / \mathrm{mL}$ & 58.600 & ns & 31.756 & ns \\
\hline \multirow{5}{*}{ LSAB } & Control & 47.242 & & 19.769 & \\
\hline & $3.125 \mathrm{mg} / \mathrm{mL}$ & 47.636 & ns & 34.728 & $* * *$ \\
\hline & $6.25 \mathrm{mg} / \mathrm{mL}$ & 34.323 & $* * *$ & 16.348 & $* *$ \\
\hline & $25 \mathrm{mg} / \mathrm{mL}$ & 35.918 & $* * *$ & 17.313 & $\mathrm{~ns}$ \\
\hline & $50 \mathrm{mg} / \mathrm{mL}$ & 35.607 & $* * *$ & 24.671 & $* *$ \\
\hline \multirow{6}{*}{ Tyrosol } & Control & 60.333 & & 33.154 & \\
\hline & $0.127 \mathrm{mM}$ & 58.664 & ns & 20.000 & $* *$ \\
\hline & $0.253 \mathrm{mM}$ & 63.046 & ns & 47.923 & $* * *$ \\
\hline & $0.506 \mathrm{mM}$ & 62.018 & $\mathrm{~ns}$ & 43.857 & $* * *$ \\
\hline & $1.013 \mathrm{mM}$ & 56.273 & ns & 38.364 & ns \\
\hline & $2.026 \mathrm{mM}$ & 58.588 & ns & 38.083 & ns \\
\hline \multirow{6}{*}{$\begin{array}{l}\text { Iso-alpha } \\
\text { humulone }\end{array}$} & Control & 79.853 & & 50.156 & \\
\hline & $2.414 \mathrm{mM}$ & 66.779 & $* * *$ & 40.510 & $* *$ \\
\hline & $9.65 \mathrm{mM}$ & 67.702 & $* * *$ & 43.529 & $* *$ \\
\hline & $19.312 \mathrm{mM}$ & 77.522 & ns & 54.035 & ns \\
\hline & $38.625 \mathrm{mM}$ & 64.205 & $* * *$ & 41.017 & $* *$ \\
\hline & $77.25 \mathrm{mM}$ & 49.824 & $* * *$ & 30.323 & $* * *$ \\
\hline
\end{tabular}

Means were calculated using the Kaplan-Meier method and the significances of the curves were determined using the log-rank method (Mantel-Cox test). ${ }^{(1)}$ ns: non-significant $(p>0.05),{ }^{*}: p<0.05,{ }^{* *}: p<0.01,{ }^{* * *}: p<0.001$.

On the other hand, LSAB significantly decreased the lifespan by over 13 days relative to their concurrent control, with the lowest concentration not affecting the lifespan. Isoalpha humulone was the substance that showed the strongest decrease in lifespan, with a significant range of between 12 and 30 days of lifespan reduction relative to its control assay (Table 3). A relationship between the characteristic phenol of beers and the activity of the full drink was also observed in the ageing trials. LBAB either makes equal or improved the effect of tyrosol, LSAB and iso-alpha humulone in the longevity treatments.

Cañuelo et al. [21] reported that the inclusion of $250 \mu \mathrm{M}$ tyrosol increased the stress resistance and lifespan in the nematode Caenorhabditis elegans. This finding agreed with our results, which confirmed the extension of Drosophila longevity at 0.253 and $0.506 \mathrm{mM}$ concentrations. Our results of iso-alpha humulone supported the stout beer results and let us hypothesise that iso-alpha humulone could be, in part, responsible for the results obtained for stout beer. Consequently, these types of ale beer should not be included in the group of nutraceutical substances. Similar studies with two types of hops showed a life expansion on Drosophila at lower assayed concentrations [29]. However, no previous research was found for ale beer and iso-alpha humulone lifespans. For this reason, it is important to take the present results with caution and carry out additional research using other organisms and biological process targets.

\subsubsection{Healthspan}

The mean survival healthspans for each substance and concentration are shown in Table 3. LBAB did not produce significant healthspan changes, except at the lowest concentration, where is significantly increased the quality of life by over 9 days compared to the water control. LSAB induced a significant improvement in healthspan in Drosophila relative to the control at the lowest and highest assayed concentrations ( 3.125 and $50 \mathrm{mg} / \mathrm{mL}$ ), with an increase of 15 and 5 days, respectively, whereas the second-to-lowest concentration 
$(6.25 \mathrm{mg} / \mathrm{mL})$ produced a slight significant decrease in healthspan in this model organism. Tyrosol showed a significant improvement in healthspan at 0.253 and $0.506 \mathrm{mM}$, with increases of 14 and 10 days, respectively, whereas the lowest concentration $(0.127 \mathrm{mM})$ produced a significant decrease in healthspan in Drosophila. Iso-alpha humulone was the compound that exhibited the worst results, as seen by the significant decrease in healthspan in Drosophila at all the assayed concentrations, except at the medium concentration $(19.312 \mathrm{mM})$, whose result was similar to the control one. The reductions ranged between 7-20 days.

This was the first time that a study of healthspan was carried out using a food supplementation with LBAB, LSAB, tyrosol and iso-alpha humulone. Not all substances should necessarily increase the lifespan of Drosophila. Assays with borage oil were carried out to evaluate its health effects and showed positive effects. In contrast, gamma-linolenic acid, which is one of the most important borage oil bioactive components, did not show these effects [45]. This pattern is similar to that displayed in the LSAB and iso-alpha humulone assays: the beverage/food/complex mixture exhibited positive effects, whereas a distinctive single compound did not show the same healthy effect in the Drosophila.

\subsection{In Vitro}

\subsubsection{Cytotoxicity}

Figure 3 shows the cytotoxicity activities when the HL-60 tumour cells were treated with LBAB, LSAB and tyrosol. These compounds showed a dose-dependent response, with the $\mathrm{IC}_{50}$ 's being lower than $62.5 \mathrm{mg} / \mathrm{mL}, 15.625 \mathrm{mg} / \mathrm{mL}$ and $0.127 \mathrm{mM}$, respectively. The cytotoxicity curve of iso-alpha humulone showed a strong dose-dependent increase of inhibition until $4.828 \mathrm{mM}$, although an increase of the cell growth at $19.3125 \mathrm{mM}$ was observed.
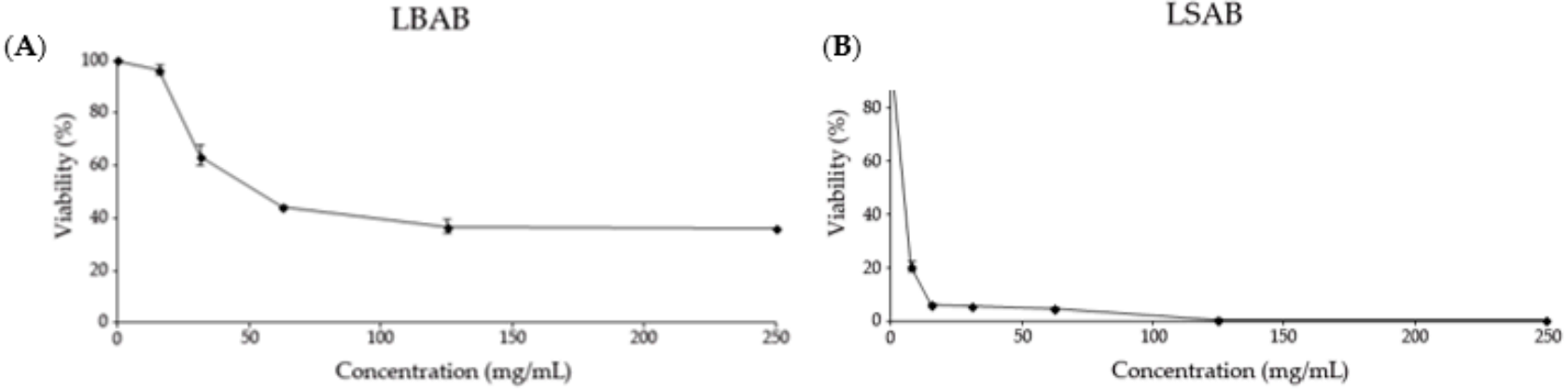

(C)

TYROSOL

(D)
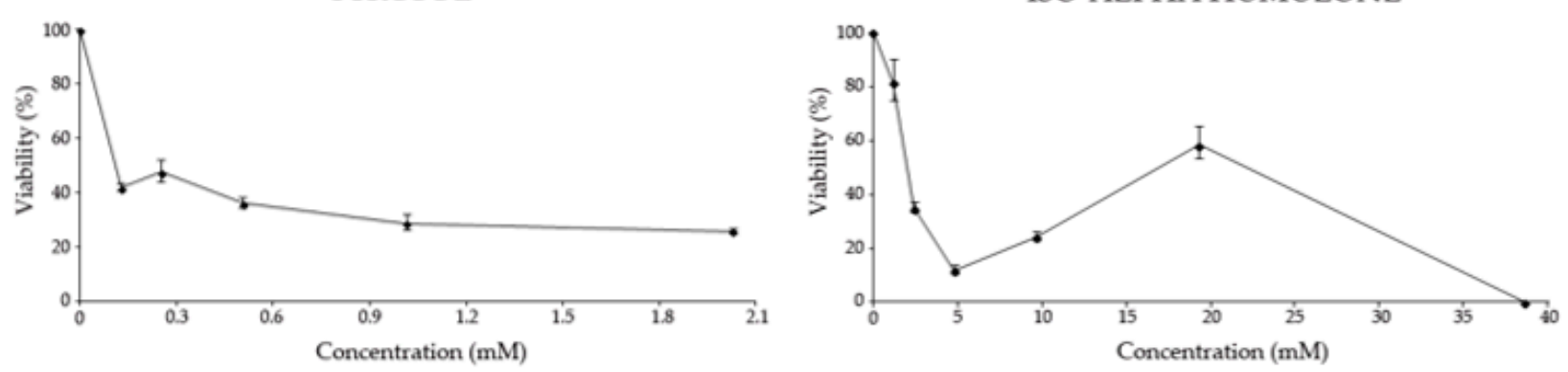

Figure 3. Effects on the cell viability of promyelocytic human leukaemia cells (HL-60) treated with different concentrations of lyophilised blond ale beer (LBAL) (A), lyophilised stout ale beer (LSAL) (B), tyrosol (C) and iso-alpha humulone (D) for $72 \mathrm{~h}$. Each point of the graph represents the growing percentage relative to the control. Data are expressed as mean $\pm \mathrm{SE}$ from three independent assays.

The interrelation between cancer risk and beer consumption is controversial. Riboli et al. [81] reported that colon cancer is not associated with beer consumption; however, Kato et al. [82] indicated an increased risk of colorectal cancer in beer drinkers. Swanson et al. [83] found 
an inverse relationship between endometrial cancer and moderate beer consumption. Potter et al. [84] reported a connection between lung cancer and beer consumption. In vitro studies demonstrated the antiproliferative activity of components of lager beer with antioxidant properties in HL-60 promyelocytic cancer cells and prostate cancer cells, exhibiting a strong association between antiproliferative activity, antioxidant potency and polyphenol content $[52,85]$. The present cytotoxic results of both types of ale beers support the epidemiological data on safety and the in vitro results of lager beer.

In relation to the phenolic compounds, studies of tyrosol in HL-60 cells, salivary glands and Caco-2 cells indicated that tyrosol was either not cytotoxic or exhibited a low level of cytotoxicity $[35,86]$. These results do not agree with ours, probably due to the different and extreme concentrations tested by the researchers (lower than $140 \mu \mathrm{M}$ and $10 \mathrm{mM})$.

Iso-alpha humulone exhibits significant biological activity against human lung and breast cancer cells in vitro [87]. According to Honma et al. [88], humulone inhibits bone resorption. Due to this property, the combination of vitamin $\mathrm{D}$ and humulone may be an interesting tool in the differentiation therapy of myelomonocytic leukaemia. According to Gerhauser [12] and Merinas-Amo et al. [29], the chemopreventive activities of hop-derived beer constituents, such as bitter acids, were reported to be significant at inhibiting the initiation, promotion and progression phases of carcinogenesis. These facts support our findings regarding the iso-alpha humulone cytotoxic assays.

\subsubsection{DNA Fragmentation}

Figure $4 \mathrm{~A}$ shows the results of the genomic integrity of HL-60 cells treated with LBAB, LSAB, tyrosol and iso-alpha humulone visualised under UV light after an electrophoresis process. Fragmentation was identified in the three lowest concentrations of LBAB $(15.625,31.25$ and $62.5 \mathrm{mg} / \mathrm{mL})$ and the two lowest concentrations of LSAB (15.625 and $31.25 \mathrm{mg} / \mathrm{mL}$ ). In addition, the highest concentrations of iso-alpha humulone (19.312 and $38.725 \mathrm{mM}$ ) were those that showed DNA fragmentation. On the other hand, tyrosol did not induce internucleosomal fragmentation at any of the assayed concentrations.

To our knowledge, none studies with LBAB and LSAB have been carried out in order to analyse the DNA fragmentation pattern induced by ale beers in cancer cells. Studies with lager beers showed a strong clastogenic/fragmentation effect of blond lager beer at the 15.625 and $31.25 \mathrm{mg} / \mathrm{L}$ concentrations and moderate effects in the intermediate concentration $(62.5 \mathrm{mg} / \mathrm{mL})$ [52]. Our results were similar to the previous results found for lager beers. Studies with tyrosol revealed its capacity to prevent apoptotic human keratin oxytic cell death against UVB radiation, pointing to its possible application in skin protection against sunlight [89]. Furthermore, Anter et al. [35] studied the effect of tyrosol on the integrity of the DNA of HL-60 cells. They showed that this phenol $(8.75-140 \mu \mathrm{M})$ did not induce proapoptotic DNA damage. Although we assayed higher concentrations, we obtained the same pattern of tyrosol, as it did not activate apoptosis in the treated HL-60 tumour cells. In relation to the humulone effects in HL-60 cells, a study supported the claim that the potent antioxidative activity might cause apoptosis [90]. These results are in agreement with ours, which showed specific DNA fragmentation that was caused by iso-alpha humulone acting as an inductor of internucleosomal proapoptotic laddering. 
A)

LBAB

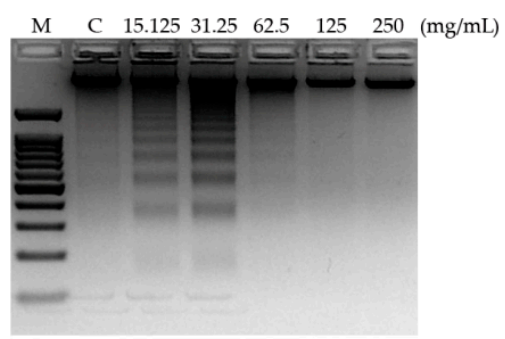

LSAB

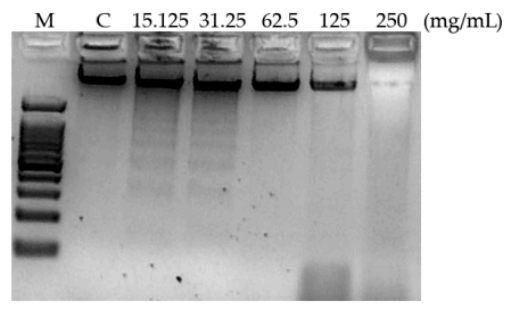

TYROSOL

$\begin{array}{llllllll}\text { M } & \text { C } & 0.127 & 0.253 & 0.506 & 1.013 & 2.026 & (\mathrm{mM})\end{array}$

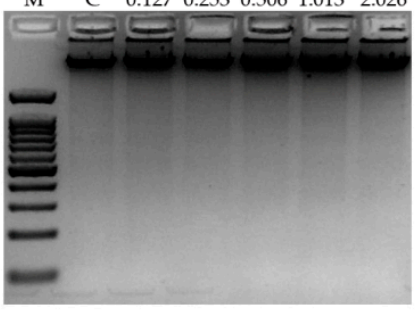

ISO-ALPHA HUMULONE

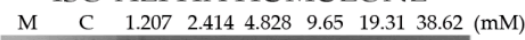

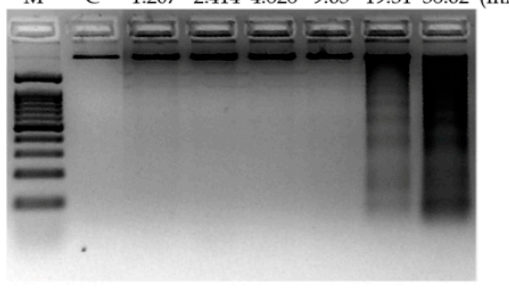

B)

LBAB

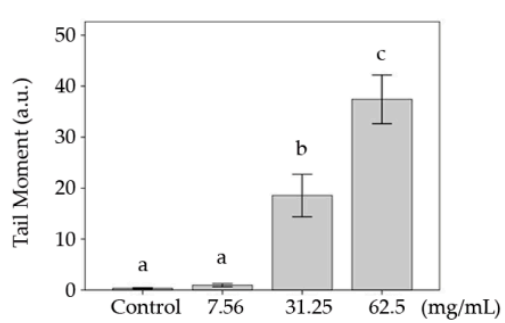

LSAB

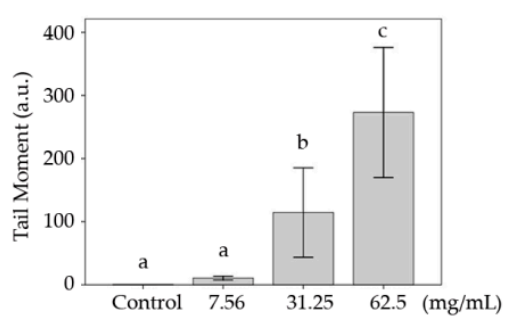

TYROSOL

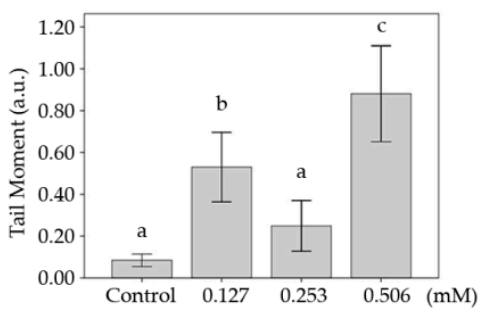

ISO-ALPHA HUMULONE

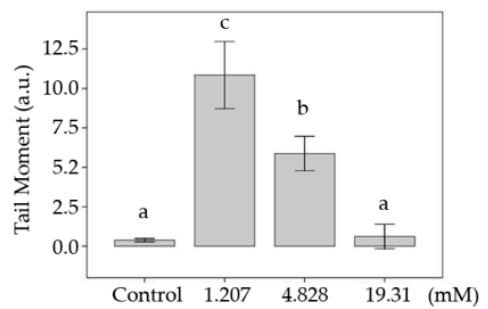

Figure 4. DNA-induced damage in promyelocytic HL-60 cells treated with different concentrations of lyophilised blond ale beer (LBAL), lyophilised stout ale beer (LSAB), tyrosol and iso-alpha humulone for $5 \mathrm{~h}$. (A) Internucleosomal DNA fragmentation. $\mathrm{M}$ indicates the DNA size marker, $\mathrm{C}$ indicates the control treatment. (B) Alkaline comet assay $(\mathrm{pH}>13)$ of the treated HL-60 cells. DNA migration is reported as the mean TM. Data are expressed as the mean \pm SE. The different letters in each treatment mean differences relative to the negative control (ANOVA followed by a post hoc Tukey's test).

\subsubsection{Comet Assay}

Figure 4B shows the tail moment of the HL-60 cells treated with different concentrations of LBAB, LSAB, tyrosol and iso-alpha humulone. A positive dose-dependent response was observed for the LBAB and LSAB treatments with significant double and/or the singlestrand breaks at the 31.2 and $62.5 \mathrm{mg} / \mathrm{mL}$ concentrations. In the tyrosol treatments, the 0.127 and $0.506 \mathrm{mM}$ concentrations showed significant TM relative to the control.

Furthermore, iso-alpha humulone exhibited a negative dose-dependent effect in the comet assay, showing significant strand breaks at the lowest concentrations (1.207 and $4.828 \mathrm{mM})$. However, similar studies with different hops showed no DNA damage at 
any level [29], which could be related to the biological interactions of the different beers' constituents in the plant matrix.

The comet assay allowed us to easily identify apoptotic nuclei based on the typical morphological cell changes attributable to DNA damage at the unicellular level with empirical data [91]. Fabiani et al. [92] proposed five classes according to the TM values. Based on this division, all concurrent control values should fall into class $0(\mathrm{TM}<1)$; LBAB 31.25 and $62.25 \mathrm{mg} / \mathrm{mL}$ showed TM values of 18 and 37, which means that they respectively induced high and complete clastogenic damage in HL-60 cells; LSAB induced damage at all the tested concentrations with a TM value of 10.6 for the lowest one, 96 for the medium concentration and 272 for the highest concentration tested; tyrosol induced TM values between 0.24 and 0.7 (class 0 ), meaning no significant damage to the cells was caused; iso-alpha humulone caused a high amount of damage at $1.207 \mathrm{mM}$ (TM value of 10.84) and a medium amount of damage at $4.828 \mathrm{mM}$ (TM value of 5.8); finally, the remaining concentrations fell into class 0 .

The comet assay TM measurements correlate with the cytotoxicity ones [93]. The results of DNA fragmentation fit well with those observed in the comet assay as TM values $>30$ mean that apoptosis mechanisms have been induced [94]. Only the highest concentration of LBAB and the two highest ones of LSAB showed TM > 30, supporting the hypothesis of leukaemia cell death by apoptosis. The rest of the compounds and concentrations tested induced cell death, although via a necrosis mechanism.

\subsubsection{Methylation Status}

Figure 5 shows the relative normalised expressions of the Sat- $\alpha$, LINE- 1 and Alu M1 repetitive sequences studied in the HL-60 cells treated with different concentrations of LBAB, LSAB, tyrosol and iso-alpha humulone. LBAB induced a significant hypermethylated status only at the lowest concentration tested $(15.625 \mathrm{mg} / \mathrm{mL})$ on the LINE-1 repetitive sequence. LSAB induced significant hypermethylation in the $15.625 \mathrm{mg} / \mathrm{mL}$ treatments on all repetitive sequences and also at the highest concentration $(250 \mathrm{mg} / \mathrm{mL})$ for the Sat- $\alpha$ sequence relative to their controls. Tyrosol showed a general tendency to methylate leukaemia cells with significant hypermethylation at $0.127 \mathrm{mM}$ for Alu M1 and Sat- $\alpha$ sequences and $2.050 \mathrm{mM}$ for the LINE-1 sequence relative to their controls. In addition, iso-alpha humulone displayed a demethylation induction on the concentrations relative to their concurrent controls.

No previous studies about methylation status with ale beers, tyrosol and iso-alpha humulone were found. Only a similar study with two types of hops showed controversial results due to both raw materials inducing methylation in LINE-1, Sat- $\alpha$ and Alu M1 sequences when they were treated at the lowest concentrations [29]. These results may be related to the biological interactions of the different beers' constituents in the plant cell matrix. At present, it is thought that the mechanisms controlling the epigenetic methylation DNA modification are multifactorial [95]. Methylation is an effective mechanism to avoid the jumping of repetitive sequences [96]. Due to the effects that methylation induces in the repetitive sequences of the genome, we could say that ale beers and tyrosol prevented epigenetic DNA damage, as the methylaltion of repetitive sequences is understood to be a genomic protective method [64,97]. These effects were not exhibited when HL-60 cells were treated with iso-alpha humulone. Our results showed that the LINE and SINE (Alu) sequences were prone to be methylated in HL-60 cells due to their genomic context or characteristics. Centromeric areas (Sat) seemed to be more protected and inaccessible. Our results in leukaemia cells showed an increase in global methylation. Besides this and taking into account the idea of tumour cells downregulating methylation, this would indicate that beer and its compounds act to avoid the repetitive sequences of tumour cells, and therefore, would be preventive agents [97]. 
(A)

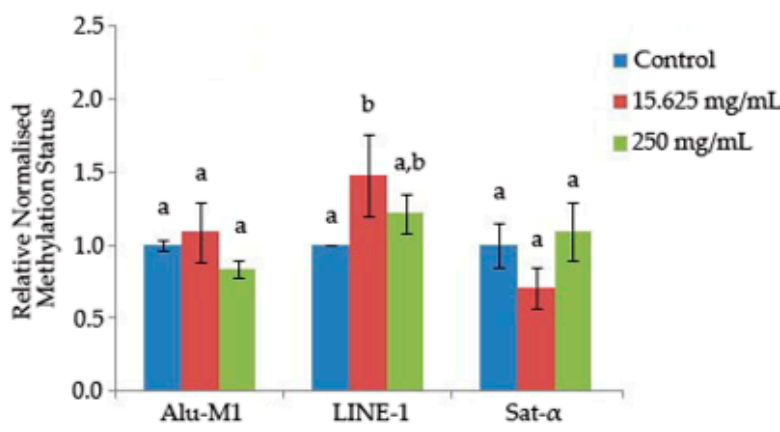

TYROSOL

(C)

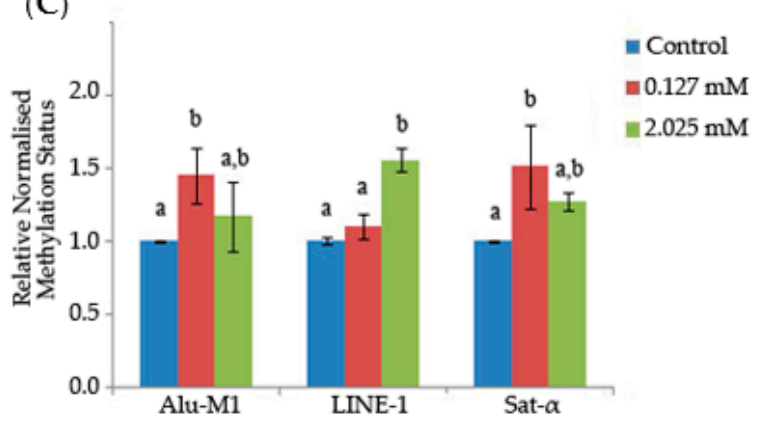

(B)

LSAB

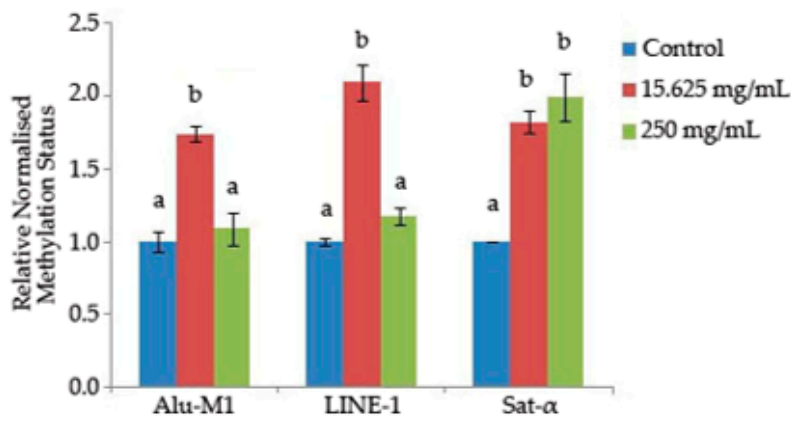

(D) ISO-ALPHA HUMULONE

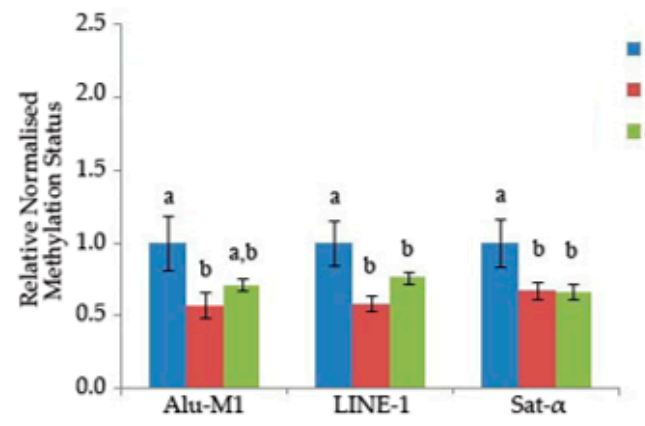

Figure 5. Relative normalised expression data of each repetitive element (Alu M1, LINE-1 and Sat- $\alpha$ ) treated with different concentrations of LBAL (A), LSAL (B), tyrosol (C) and iso-alpha humulone (D). Different letters (a and b) indicate significant differences (ANOVA followed by a post hoc Tukey's test).

\section{Conclusions}

Several approaches at the individual, cellular and DNA levels were used to study the biological activities of two ale beers (LBAB and LSAB) and their most abundant biophenols (tyrosol and iso-alpha humulone).

All the assays carried out indicated a high potency of lyophilised blond and stout ale beers to modulate degenerative processes. The safety (non toxic and non genotoxic properties), the protection against the oxidative genotoxine $\mathrm{H}_{2} \mathrm{O}_{2}$ (antitoxic and antigenotoxic activities), the extension of lifespan in D. melanogaster (only for LBAB), the induction of clastogenic proapoptotic DNA damage in individual tumour cells and DNA fragmentation and the modulation of methylation status were established. The phenolic alcohol included in beer exhibited most of the activities of the blond ale beer as a complex mixture: it showed antitoxic effects at higher concentrations, the curve of cells growing was similar to the beers' curves and it induced a hypermethylation status in tumour cells. The hop acid showed similar activities to the stout ale beer as a complex mixture: it showed antitoxic effects at lower concentrations, reduced the lifespan of the animal model and induced a $100 \%$ inhibition of tumour cell growth. On the other hand, some interesting peculiarities have to be noted: tyrosol showed maintenance of the lifespan effect in Drosophila and did not induce proapoptotic DNA fragmentation or DNA strand breaks and iso-alpha humulone induced single-strand breaks at lower concentrations, whereas the DNA damage was induced by beers was at higher concentrations; different patterns in the methylation status was observed for the compounds relative to beers. For these reasons, the biological activities assigned to beer consumption cannot be linked to one particular constituent due to the high variability and complexity in the polyphenolic profile; furthermore, brewing is influenced by many factors, such as the raw materials, yeast strains, wort composition and fermentation conditions. To sum up, the results put forward showed that daily moderate 
ingestion of beer may be conducive to good health because of the attributes that the full drink shows.

Author Contributions: Formal analysis, R.M.-A.; conceptualisation, Á.A.-M.; investigation, R.F.; writing, review and editing, T.M.-A.; supervision, M.d.R.C. All authors have read and agreed to the published version of the manuscript.

Funding: No external funding was received.

Institutional Review Board Statement: Not applicable.

Informed Consent Statement: Not applicable.

Data Availability Statement: The data presented in this study are available on request from the corresponding author.

Conflicts of Interest: The authors declare no conflict of interest.

\section{References}

1. Martín-Moreno, J.M.; Soerjomataram, I.; Magnusson, G. Cancer causes and prevention: A condensed appraisal in Europe in 2008. Eur. J. Cancer 2008, 44, 1390-1403. [CrossRef]

2. Reddy, L.; Odhav, B.; Bhoola, K. Natural products for cancer prevention: A global perspective. Pharmacol. Ther. 2003, 99, 1-13. [CrossRef]

3. Doll, R.; Peto, R. The Causes of Cancer: Quantitative Estimates of Avoidable Risks of Cancer in the United States Today. J. Natl. Cancer Inst. 1981, 66, 1192-1308. [CrossRef]

4. Clayton, D.; McKeigue, P.M. Epidemiological methods for studying genes and environmental factors in complex diseases. Lancet 2001, 358, 1356-1360. [CrossRef]

5. Walker, J.; Hell, J.; Liszt, K.I.; Dresel, M.; Pignitter, M.; Hofmann, T.; Somoza, V. Identification of Beer Bitter Acids Regulating Mechanisms of Gastric Acid Secretion. J. Agric. Food Chem. 2012, 60, 1405-1412. [CrossRef]

6. Piendl, A. On the importance of beer in nutrition today. Brauwelt 1989, 124, 546-552.

7. Chen, W.; Becker, T.; Qian, F.; Ring, J. Beer and beer compounds: Physiological effects on skin health. J. Eur. Acad. Dermatol. Venereol. 2013, 28, 142-150. [CrossRef] [PubMed]

8. Buiatti, S. Chapter 20-Beer Composition: An Overview; Academic Press: London, UK, 2009; pp. 212-225.

9. Rimm, E.; Giovannucci, E.; Willett, W.; Colditz, G.; Ascherio, A.; Rosner, B.; Stampfer, M. Prospective study of alcohol consumption and risk of coronary disease in men. Lancet 1991, 338, 464-468. [CrossRef]

10. Muller, R.; Walker, S.; Brauer, J.; Junquera, M. Does Beer Contain Compounds That Might Interfere with Cholesterol Metabolism? J. Inst. Brew. 2007, 113, 102-109. [CrossRef]

11. Curhan, G.C.; Willett, W.C.; Rimm, E.B.; Spiegelman, D.; Stampfer, M.J. Prospective Study of Beverage Use and the Risk of Kidney Stones. Am. J. Epidemiol. 1996, 143, 240-247. [CrossRef]

12. Gerhäuser, C. Beer constituents as potential cancer chemopreventive agents. Eur. J. Cancer 2005, 41, 1941-1954. [CrossRef] [PubMed]

13. Preedy, V.R. Beer in Health and Disease Prevention; Academic Press: Cambridge, MA, USA, 2011.

14. Dewapriya, P.; Himaya, S.; Li, Y.-X.; Kim, S.-K.; Hewage, H.S.W. Tyrosol exerts a protective effect against dopaminergic neuronal cell death in in vitro model of Parkinson's disease. Food Chem. 2013, 141, 1147-1157. [CrossRef] [PubMed]

15. Tressl, R.; Renner, R.; Apetz, M. Volatile phenolic components in beer, smoked beer, and sherry (author's transl). Zeitschrift fuer Lebensmittel-Untersuchung und-Forschung 1976, 162, 115. [CrossRef] [PubMed]

16. Mateos, R.; Domínguez, M.M.; Espartero, A.J.L.; Cert, A. Antioxidant Effect of Phenolic Compounds, $\alpha$-Tocopherol, and Other Minor Components in Virgin Olive Oil. J. Agric. Food Chem. 2003, 51, 7170-7175. [CrossRef] [PubMed]

17. Rietjens, S.J.; Bast, A.; De Vente, J.; Haenen, G.R.M.M. The olive oil antioxidant hydroxytyrosol efficiently protects against the oxidative stress-induced impairment of the NO response of isolated rat aorta. Am. J. Physiol. Circ. Physiol. 2007, 292, H1931-H1936. [CrossRef] [PubMed]

18. Giovannini, C.; Straface, E.; Modesti, D.; Coni, E.; Cantafora, A.; De Vincenzi, M.; Malorni, W.; Masella, R. Tyrosol, the Major Olive Oil Biophenol, Protects Against Oxidized-LDL-Induced Injury in Caco-2 Cells. J. Nutr. 1999, 129, 1269-1277. [CrossRef] [PubMed]

19. Samuel, S.M.; Thirunavukkarasu, M.; Penumathsa, S.V.; Paul, D.; Maulik, N. Akt/FOXO3a/SIRT1-mediated cardioprotection by $\mathrm{n}$-tyrosol against ischemic stress in rat in vivo model of myocardial infarction: Switching gears toward survival and longevity. $J$. Agric. Food Chem. 2008, 56, 9692-9698. [CrossRef]

20. Sun, L.; Isaak, C.K.; Zhou, Y.; Petkau, J.C.; Liu, Y.; Siow, Y.L. Salidroside and tyrosol from Rhodiola protect H9c2 cells from ischemia/reperfusion-induced apoptosis. Life Sci. 2012, 91, 151-158. [CrossRef] 
21. Cañuelo, A.; Gilbert-López, B.; Pacheco-Liñán, P.; Martínez-Lara, E.; Siles-Rivas, E.; Miranda-Vizuete, A. Tyrosol, a main phenol present in extra virgin olive oil, increases lifespan and stress resistance in Caenorhabditis elegans. Mech. Ageing Dev. 2012, 133, 563-574. [CrossRef]

22. Bu, Y.; Rho, S.; Kim, J.; Kim, M.Y.; Lee, D.H.; Kim, S.Y.; Choi, H.; Kim, H. Neuroprotective effect of tyrosol on transient focal cerebral ischemia in rats. Neurosci. Lett. 2007, 414, 218-221. [CrossRef]

23. De Keukeleire, J.; Ooms, G.; Heyerick, A.; Roldán-Ruiz, I.; Van Bockstaele, E.; De Keukeleire, D. Formation and Accumulation of $\alpha$-Acids, $\beta$-Acids, Desmethylxanthohumol, and Xanthohumol during Flowering of Hops (Humulus lupulusL.). J. Agric. Food Chem. 2003, 51, 4436-4441. [CrossRef]

24. De Keukeleire, D. Fundamentals of beer and hop chemistry. Química Nova 2000, 23, 108-112. [CrossRef]

25. Verzele, M.; De Keukeleire, D. Chemistry and Analysis of Hop and Beer Bitter Acids; Elsevier: Amsterdam, The Netherlands, 2013; Volume 27.

26. Lu, Y.; Bergenståhl, B. Condensation of iso-humulone in solution and at hydrophobic surfaces. Colloids Surf. A Physicochem. Eng. Asp. 2021, 613, 126102. [CrossRef]

27. Lu, Y.; Bergenståhl, B.; Nilsson, L. Interfacial properties and interaction between beer wort protein fractions and iso-humulone. Food Hydrocoll. 2020, 103, 105648. [CrossRef]

28. Simpson, W.J. Ionophoric action of trans-isohumulone on Lactobacillus brevis. J. Gen. Microbiol. 1993, 139, 1041-1045. [CrossRef]

29. Merinas-Amo, T.; Merinas-Amo, R.; García-Zorrilla, V.; Velasco-Ruiz, A.; Chladek, L.; Plachy, V.; Del Río-Celestino, M.; Font, R.; Kokoska, L.; Alonso-Moraga, Á. Toxicological Studies of Czech Beers and Their Constituents. Foods 2019, 8, 328. [CrossRef]

30. Bohra, G.; Klimob, K.; Beckera, H.; Gerhäuserb, C. Cancer chemopreventive potential of humulones and isohumulones (hops $\alpha$-and iso- $\alpha$-acids): Induction of NAD (P) H: Quinone reductase as a novel mechanism. Nat. Prod. Commun. 2008, 3, 1934578X0800301206. [CrossRef]

31. Yamamoto, K.; Wang, J.; Yamamoto, S.; Tobe, H. Suppression of cyclooxygenase-2 gene transcription by humulon of beer hop extract studied with reference to glucocorticoid. FEBS Lett. 2000, 465, 103-106. [CrossRef]

32. Lee, J.-C.; Kundu, J.K.; Hwang, D.-M.; Na, H.-K.; Surh, Y.-J. Humulone inhibits phorbol ester-induced COX-2 expression in mouse skin by blocking activation of NF- $\mathrm{KB}$ and $\mathrm{AP}-1$ : I $\mathrm{KB}$ kinase and $\mathrm{c}-\mathrm{Jun}-\mathrm{N}$-terminal kinase as respective potential upstream targets. Carcinogenesis 2007, 28, 1491-1498. [CrossRef] [PubMed]

33. Shimamura, M.; Hazato, T.; Ashino, H.; Yamamoto, Y.; Iwasaki, E.; Tobe, H.; Yamamoto, K.; Yamamoto, S. Inhibition of Angiogenesis by Humulone, a Bitter Acid from Beer Hop. Biochem. Biophys. Res. Commun. 2001, 289, 220-224. [CrossRef]

34. Sánchez, C.L.; Franco, L.; Bravo, R.; Rubio, C.; Rodríguez, A.B.; Barriga, C.; Cubero, J. Cerveza y salud, beneficios en el sueño. Rev. Esp. Nutr. Comunitaria. 2010, 16, 160-163. [CrossRef]

35. Anter, J.; Campos-Sánchez, J.; El Hamss, R.; Rojas-Molina, M.; Muñoz-Serrano, A.; Analla, M.; Alonso-Moraga, Á. Modulation of genotoxicity by extra-virgin olive oil and some of its distinctive components assessed by use of the Drosophila wing-spot test. Mutat. Res. Toxicol. Environ. Mutagen. 2010, 703, 137-142. [CrossRef]

36. Richardson, H.E.; Willoughby, L.; Humbert, P.O. Screening for Anti-cancer Drugs in Drosophila. eLS 2015, 1-14.

37. Graf, U.; Würgler, F.E.; Katz, A.J.; Frei, H.; Juon, H.; Hall, C.B.; Kale, P.G. Somatic mutation and recombination test in Drosophila melanogaster. Environ. Mutagen. 1984, 6, 153-188. [CrossRef] [PubMed]

38. Ja, W.W.; Carvalho, G.B.; Mak, E.M.; De La Rosa, N.N.; Fang, A.Y.; Liong, J.C.; Brummel, T.; Benzer, S. Prandiology of Drosophila and the CAFE assay. Proc. Natl. Acad. Sci. USA 2007, 104, 8253-8256. [CrossRef]

39. Kirin. Globar Beer Consumption by Country in 2011. Available online: http://www.kirinholdings.co.jp/english/news/2015/1 224_01.html (accessed on 24 December 2015).

40. Gonzalez, C. Drosophila melanogaster: A model and a tool to investigate malignancy and identify new therapeutics. Nat. Rev. Cancer 2013, 13, 172-183. [CrossRef] [PubMed]

41. Lints, F.A.; Soliman, M.H. Drosophila as a Model Organism for Ageing Studies; Springer: Berlin/Heidelberg, Germany, 1988.

42. Rudrapatna, V.A.; Cagan, R.L.; Das, T.K. Drosophila cancer models. Dev. Dyn. 2011, 241, 107-118. [CrossRef]

43. Yan, J.; Huen, D.; Morely, T.; Johnson, G.; Gubb, D.; Roote, J.; Adler, P.N. The multiple-wing-hairs Gene Encodes a Novel GBD-FH3 Domain-Containing Protein That Functions Both Prior to and After Wing Hair Initiation. Genetics 2008, 180, $219-228$. [CrossRef]

44. Ren, N.; Charlton, J.; Adler, P.N. The flare Gene, Which Encodes the AIP1 Protein of Drosophila, Functions to Regulate F-Actin Disassembly in Pupal Epidermal Cells. Genetics 2007, 176, 2223-2234. [CrossRef] [PubMed]

45. Tasset-Cuevas, I.; Fernández-Bedmar, Z.; Lozano-Baena, M.D.; Campos-Sánchez, J.; De Haro-Bailón, A.; Muñoz-Serrano, A.; Alonso-Moraga, Á. Protective Effect of Borage Seed Oil and Gamma Linolenic Acid on DNA: In Vivo and In Vitro Studies. PLoS ONE 2013, 8, e56986. [CrossRef] [PubMed]

46. Graf, U.; Abraham, S.K.; Guzmán-Rincón, J.; Würgler, F.E. Antigenotoxicity studies in Drosophila melanogaster. Mutat. Res. Mol. Mech. Mutagen. 1998, 402, 203-209. [CrossRef]

47. Frei, H.; Würgler, F. Statistical methods to decide whether mutagenicity test data from Drosophila assays indicate a positive, negative, or inconclusive result. Mutat. Res. Mutagen. Relat. Subj. 1988, 203, 297-308. [CrossRef]

48. Frei, H.; Würgler, F.E. Optimal experimental design and sample size for the statistical evaluation of data from somatic mutation and recombination tests (SMART) in Drosophila. Mutat. Res. Mutagen. Relat. Subj. 1995, 334, 247-258. [CrossRef] 
49. Abraham, S.K. Antigenotoxicity of coffee in the Drosophila assay for somatic mutation and recombination. Mutagenesis 1994, 9 , 383-386. [CrossRef] [PubMed]

50. Soh, J.W.; Hotic, S.; Arking, R. Dietary restriction in Drosophila is dependent on mitochondrial efficiency and constrained by pre-existing extended longevity. Mech. Ageing Dev. 2007, 128, 581-593. [CrossRef] [PubMed]

51. Gallagher, R.; Collins, S.; Trujillo, J.; McCredie, K.; Ahearn, M.; Tsai, S.; Metzgar, R.; Aulakh, G.; Ting, R.; Ruscetti, F.; et al. Characterization of the continuous, differentiating myeloid cell line (HL-60) from a patient with acute promyelocytic leukemia. Blood 1979, 54, 713-733. [CrossRef] [PubMed]

52. Merinas-Amo, T.; Tasset-Cuevas, I.; Díaz-Carretero, A.M.; Alonso-Moraga, Á.; Calahorro, F. In vivo and in vitro studies of the role of lyophilised blond Lager beer and some bioactive components in the modulation of degenerative processes. J. Funct. Foods 2016, 27, 274-294. [CrossRef]

53. Husseini, G.A.; El-Fayoumi, R.I.; O’Neill, K.L.; Rapoport, N.Y.; Pitt, W.G. DNA damage induced by micellar-delivered doxorubicin and ultrasound: Comet assay study. Cancer Lett. 2000, 154, 211-216. [CrossRef]

54. Olive, P.L.; Banáth, J.P. The comet assay: A method to measure DNA damage in individual cells. Nat. Protoc. 2006, 1, 23-29. [CrossRef]

55. Prosperini, A.; Juan-García, A.; Font, G.; Ruiz, M. Beauvericin-induced cytotoxicity via ROS production and mitochondrial damage in Caco-2 cells. Toxicol. Lett. 2013, 222, 204-211. [CrossRef] [PubMed]

56. Mateo-Fernández, M.; Merinas-Amo, T.; Moreno-Millán, M.; Alonso-Moraga, Á.; Demyda-Peyrás, S. In vivo and in vitro genotoxic and epigenetic effects of two types of cola beverages and caffeine: A multi-assay approach. Bio. Med. Res. Int. 2016, 2016, 15.

57. Kumaravel, T.S.; Vilhar, B.; Faux, S.P.; Jha, A.N. Comet Assay measurements: A perspective. Cell Biol. Toxicol. 2007, 25, 53-64. [CrossRef] [PubMed]

58. Deininger, P.L.; Moran, J.V.; Batzer, M.A.; Kazazian, H.H. Mobile elements and mammalian genome evolution. Curr. Opin. Genet. Dev. 2003, 13, 651-658. [CrossRef] [PubMed]

59. Ehrlich, M. DNA Hypomethylation, Cancer, the Immunodeficiency, Centromeric Region Instability, Facial Anomalies Syndrome and Chromosomal Rearrangements. J. Nutr. 2002, 132, 2424S-2429S. [CrossRef]

60. Lee, C.; Wevrick, R.; Fisher, R.B.; Ferguson-Smith, M.A.; Lin, C.C. Human centromeric DNAs. Qual. Life Res. 1997, 100, 291-304. [CrossRef]

61. Weiner, A.M. SINEs and LINEs: The art of biting the hand that feeds you. Curr. Opin. Cell Biol. 2002, 14, 343-350. [CrossRef]

62. Nikolaidis, G.; Raji, O.Y.; Markopoulou, S.; Gosney, J.R.; Bryan, J.; Warburton, C.; Walshaw, M.; Sheard, J.; Field, J.K.; Liloglou, T. DNA Methylation Biomarkers Offer Improved Diagnostic Efficiency in Lung Cancer. Cancer Res. 2012, 72, 5692-5701. [CrossRef] [PubMed]

63. Liloglou, T.; Bediaga, N.G.; Brown, B.R.; Field, J.K.; Davies, M.P. Epigenetic biomarkers in lung cancer. Cancer Lett. 2014, 342, 200-212. [CrossRef]

64. Weisenberger, D.J.; Campan, M.; Long, T.I.; Kim, M.; Woods, C.; Fiala, E.; Ehrlich, M.; Laird, P.W. Analysis of repetitive element DNA methylation by MethyLight. Nucleic Acids Res. 2005, 33, 6823-6836. [CrossRef] [PubMed]

65. Romero-Jiménez, M.; Campos-Sánchez, J.; Analla, M.; Muñoz-Serrano, A.; Alonso-Moraga, Á. Genotoxicity and anti-genotoxicity of some traditional medicinal herbs. Mutat. Res. Toxicol. Environ. Mutagen. 2005, 585, 147-155. [CrossRef]

66. Gorjanovic, S.Z.; Novaković, M.M.; Vukosavljevic, P.V.; Pastor, F.T.; Tesevic, V.V.; Sužnjević, D.Z. Polarographic Assay Based on Hydrogen Peroxide Scavenging in Determination of Antioxidant Activity of Strong Alcohol Beverages. J. Agric. Food Chem. 2010, 58, 8400-8406. [CrossRef]

67. Medina, E.; De Castro, A.; Romero, C.; Brenes, M. Comparison of the Concentrations of Phenolic Compounds in Olive Oils and Other Plant Oils: Correlation with Antimicrobial Activity. J. Agric. Food Chem. 2006, 54, 4954-4961. [CrossRef]

68. De Keukeleire, D.; De Cooman, L.; Rong, H.; Heyerick, A.; Kalita, J.; Milligan, S.R. Functional properties of hop polyphenols. In Basic Life Sciences; Springer International Publishing: Berlin/Heidelberg, Germany, 1999; Volume 66, pp. 739-760.

69. Halliwell, B.; Gutteridge, J. Cellular responses to oxidative stress: Adaptation, damage, repair, senescence and death. Free Radic. Biol. Med. 2007, 4, 187-267.

70. Rice-Evans, C.A.; Miller, N.J.; Paganga, G. Structure-antioxidant activity relationships of flavonoids and phenolic acids. Free. Radic. Biol. Med. 1996, 20, 933-956. [CrossRef]

71. Yamanaka, N.; Oda, O.; Nagao, S. Green tea catechins such as (-)-epicatechin and (-)-epigallocatechin accelerate Cu2+-induced low density lipoprotein oxidation in propagation phase. FEBS Lett. 1997, 401, 230-234. [CrossRef]

72. Loru, D.; Incani, A.; Deiana, M.; Corona, G.; Atzeri, A.; Melis, M.; Rosa, A.; Dessì, M. Protective effect of hydroxytyrosol and tyrosol against oxidative stress in kidney cells. Toxicol. Ind. Health 2009, 25, 301-310. [CrossRef] [PubMed]

73. Liégeois, C.; Lermusieau, G.; Collin, S. Measuring Antioxidant Efficiency of Wort, Malt, and Hops against the 2,2'-Azobis(2amidinopropane) Dihydrochloride-Induced Oxidation of an Aqueous Dispersion of Linoleic Acid. J. Agric. Food Chem. 2000, 48, 1129-1134. [CrossRef] [PubMed]

74. Tafulo, P.A.R.; Queirós, R.B.; Delerue-Matos, C.M.; Sales, M.G.F. Control and comparison of the antioxidant capacity of beers. Food Res. Int. 2010, 43, 1702-1709. [CrossRef]

75. Granato, D.; Branco, G.F.; Faria, J.D.A.F.; Cruz, A.G. Characterization of Brazilian lager and brown ale beers based on color, phenolic compounds, and antioxidant activity using chemometrics. J. Sci. Food Agric. 2010, 91, 563-571. [CrossRef] 
76. Anter, J.; Romero-Jiménez, M.; Fernández-Bedmar, Z.; Villatoro-Pulido, M.; Analla, M.; Alonso-Moraga, Á.; Muñoz-Serrano, A. Antigenotoxicity, Cytotoxicity, and Apoptosis Induction by Apigenin, Bisabolol, and Protocatechuic Acid. J. Med. Food 2011, 14, 276-283. [CrossRef]

77. Arimoto-Kobayashi, S.; Ishida, R.; Nakai, Y.; Idei, C.; Takata, J.; Takahashi, E.; Okamoto, K.; Negishi, T.; Konuma, T. Inhibitory Effects of Beer on Mutation in the Ames Test and DNA Adduct Formation in Mouse Organs Induced by 2-Amino-1-methyl-6phenylimidazo[4,5-b]pyridine (PhIP). Biol. Pharm. Bull. 2006, 29, 67-70. [CrossRef]

78. Fleming, J.; Reveillaud, I.; Niedzwiecki, A. Role of oxidative stress in Drosophila aging. Mutat. Res. 1992, 275, 267-279. [CrossRef]

79. Guarente, L.; Kenyon, C. Genetic pathways that regulate ageing in model organisms. Nat. Cell Biol. 2000, 408, 255-262. [CrossRef] [PubMed]

80. Deshpande, S.A.; Carvalho, G.B.; Amador, A.; Phillips, A.M.; Hoxha, S.; Lizotte, K.J.; Ja, W.W. Quantifying Drosophila food intake: Comparative analysis of current methodology. Nat. Methods 2014, 11, 535-540. [CrossRef] [PubMed]

81. Riboli, E.; Cornée, J.; Macquart-Moulin, G.; Kaaks, R.; Casagrande, C.; Guyader, M. Cancer and Polyps of the Colorectum and Lifetime Consumption of Beer and Other Alcoholic Beverages. Am. J. Epidemiology 1991, 134, 157-166. [CrossRef]

82. Kato, I.; Tominaga, S.; Ikari, A. A Case-Control Study of Male Colorectal Cancer in Aichi Prefecture, Japan: With Special Reference to Occupational Activity Level, Drinking Habits and Family History. Jpn. J. Cancer Res. 1990, 81, 115-121. [CrossRef]

83. Swanson, C.A.; Wilbanks, G.D.; Twiggs, L.B.; Monet, R.; Berman, M.L.; Barrett, R.J.; Brintonl, L.A. Moderate Alcohol Consumption and the Risk of Endometrial Cancer. Epidemiology 1993, 4, 530-536. [CrossRef]

84. Potter, J.D.; Sellers, T.A.; Folsom, A.R.; McGovern, P.G. Alcohol, beer, and lung cancer in postmenopausal women The iowa women's health study. Ann. Epidemiol. 1992, 2, 587-595. [CrossRef]

85. Hevia, D.; Mayo, J.C.; Quiros, I.; Sainz, R. Beer constituents inhibit prostate cancer cells proliferation. Eur. J. Cancer Suppl. 2008, 6, 142. [CrossRef]

86. Babich, H.; Visioli, F. In vitro cytotoxicity to human cells in culture of some phenolics from olive oil. Il Farm. 2003, 58, 403-407. [CrossRef]

87. Tyrrell, E.; Archer, R.; Skinner, G.; Singh, K.; Colston, K.; Driver, C. Structure elucidation and an investigation into the in vitro effects of hop acids on human cancer cells. Phytochem. Lett. 2010, 3, 17-23. [CrossRef]

88. Honma, Y.; Tobe, H.; Makishima, M.; Yokoyama, A.; Okabe-Kado, J. Induction of differentiation of myelogenous leukemia cells by humulone, a bitter in the hop. Leuk. Res. 1998, 22, 605-610. [CrossRef]

89. Salucci, S.; Burattini, S.; Curzi, D.; Buontempo, F.; Martelli, A.M.; Zappia, G.; Falcieri, E.; Battistelli, M. Antioxidants in the prevention of UVB-induced keratynocyte apoptosis. J. Photochem. Photobiol. B Biol. 2014, 141, 1-9. [CrossRef] [PubMed]

90. Tobe, H.; Kubota, M.; Yamaguchi, M.; Kocha, T.; Aoyagi, T. Apoptosis to HL-60 by Humulone. Biosci. Biotechnol. Biochem. 1997, 61, 1027-1029. [CrossRef] [PubMed]

91. Poe, B.S.; O'Neill, K.L. Caffeine modulates heat shock induced apoptosis in the human promyelocytic leukemia cell line HL-60. Cancer Lett. 1997, 121, 1-6. [CrossRef]

92. Fabiani, R.; Rosignoli, P.; De Bartolomeo, A.; Fuccelli, R.; Morozzi, G. Genotoxicity of alkene epoxides in human peripheral blood mononuclear cells and HL60 leukaemia cells evaluated with the comet assay. Mutat. Res. Toxicol. Environ. Mutagen. 2012, 747, 1-6. [CrossRef]

93. Fairbairn, D.W.; Walburger, D.K.; Fairbairn, J.J.; O'Neill, K.L. Key morphologic changes and DNA strand breaks in human lymphoid cells: Discriminating apoptosis from necrosis. Scanning 2006, 18, 407-416. [CrossRef]

94. Fairbairn, D.W.; Olive, P.L.; O'Neill, K.L. The comet assay: A comprehensive review. Mutat. Res. Genet. Toxicol. 1995, 339, 37-59. [CrossRef]

95. Herman, J.G.; Baylin, S.B. Gene Silencing in Cancer in Association with Promoter Hypermethylation. New Engl. J. Med. 2003, 349, 2042-2054. [CrossRef]

96. Esteller, M. DNA methylation and cancer therapy: New developments and expectations. Curr. Opin. Oncol. 2005, 17, 55-60. [CrossRef]

97. Román-Gómez, J.; Jiménez-Velasco, A.; Agirre, X.; Castillejo, J.A.; Navarro, G.; José-Enériz, E.S.; Garate, L.; Cordeu, L.; Cervantes, F.; Prosper, F.; et al. Repetitive DNA hypomethylation in the advanced phase of chronic myeloid leukemia. Leuk. Res. 2008, 32, 487-490. [CrossRef] [PubMed] 